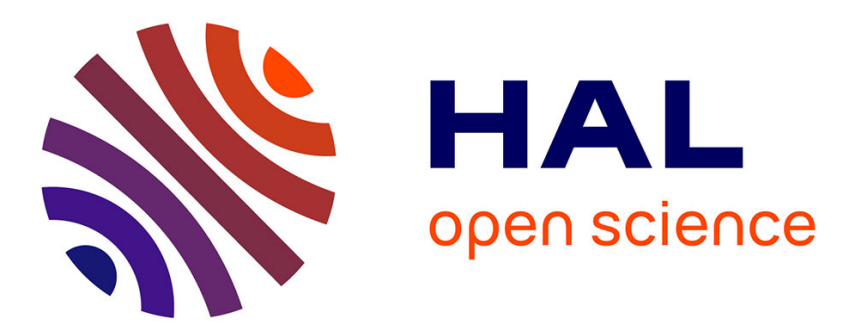

\title{
Interaction between Kondratieff Waves and Juglar Cycles
}

\author{
Leonid Grinin, Andrey Korotayev
}

\section{To cite this version:}

Leonid Grinin, Andrey Korotayev. Interaction between Kondratieff Waves and Juglar Cycles. Leonid Grinin. Kondratieff Waves. Juglar - Kuznets - Kondratieff. Yearbook, 2014, Leonid Grinin, pp.25 95, 2014, 978-5-7057-4282-0. hprints-01863102

\section{HAL Id: hprints-01863102 \\ https://hal-hprints.archives-ouvertes.fr/hprints-01863102}

Submitted on 28 Aug 2018

HAL is a multi-disciplinary open access archive for the deposit and dissemination of scientific research documents, whether they are published or not. The documents may come from teaching and research institutions in France or abroad, or from public or private research centers.
L'archive ouverte pluridisciplinaire HAL, est destinée au dépôt et à la diffusion de documents scientifiques de niveau recherche, publiés ou non, émanant des établissements d'enseignement et de recherche français ou étrangers, des laboratoires publics ou privés. 


\title{
I. THE SYSTEM OF CYCLES
}

\section{1 \\ Interaction between Kondratieff Waves and Juglar Cycles*}

\author{
Leonid E. Grinin and Andrey V. Korotayev
}

\begin{abstract}
Some important correlations between medium-term economic cycles (711 years) known as Juglar cycles and long (40-60 years) Kondratieff cycles are presented in this paper. The research into the history of this issue shows that this aspect is insufficiently studied. Meanwhile, in our opinion, it can significantly clarify both the reasons of alternation of upswing and downswing phases in $K$-waves and the reasons of relative stability of the length of these waves. It also can provide the certain means for forecasting. The authors show that adjacent 2-4 medium cycles form the system the important characteristic of which is the dynamics of economic trend. The latter can be upswing (active) or downswing (depressive). The mechanisms of formation of such medium-term trends and changing tendencies are explained. The presence of such clusters of medium cycles (general duration of which is 20-30 years) determines to a large degree the long-wave dynamics and the characteristics of its timing. Thus, not medium-term J-cycles depend on the character of K-wave phase as Kondratieff supposed, but the character of the cluster of J-cycles determines significantly the character of $K$-wave phases.
\end{abstract}

Keywords: medium-term cycles, Juglar cycles, long cycles of Kondratieff, long waves, downswing phase, upswing phase, crisis, resources, business strategies, generations of businessmen.

\section{Introductory Notes}

'It appears that crises, like diseases, are one of the conditions of the existence of those societies where trade and industry are prevalent. One can predict them, alleviate them, delay them up to a certain moment, one can facilitate the recovery

\footnotetext{
* This research has been supported by the Russian Science Foundation (Project No 14-11-00634) and implemented as part of the Basic Research Program at the National Research University Higher School of Economics (HSE) in 2015.

Kondratieff Waves: Juglar - Kuznets - Kondratieff 2014 25-95
} 
of economic activities; but it has turned to be impossible to eliminate them notwithstanding all the possible methods that have been applied'. Unfortunately, those well-forgotten words of Clement Juglar (1862: VII), who was one of the first to demonstrate that economic crises follow the periodical/cyclical pattern, became very relevant again in 2008 , that is about 150 years after they had been written.

We will start this article with our analysis of the main features of mediumterm cycles of business activity, or business cycles (7-11 years) ${ }^{1}$ that are also known as Juglar cycles after the prominent $19^{\text {th }}$-century French economist Clement Juglar (1819-1905), who investigated these cycles in detail (Idem $1862,1889)^{2}$

Juglar investigated fluctuations of prices, discount rates and gold reserves of banks in France, England, and the USA and showed their correlation with cycles of increasing business activity, investments (and speculations), and employment (Ibid.).The first edition of his book was published in 1862. Juglar's most important achievement lay in presenting substantial evidence that crises were periodical, that is in support of 'the law of crises' periodicity'. According to this law, crisis is preceded by epochs of recovery, well-being, and price increases, which are followed by years of price decrease and trade slowing down that bring economy into a depressed state (Idem 1889: xv). The transition of economics as a whole from crisis theory to business-cycle theory is frequently connected (Besomi 2005: 1) with Juglar's contribution to analysis of periodical crises. Thus, crisis does not occur randomly (it is erroneous to ascribe its occurrence to random factors). ${ }^{3}$ It is preceded by an intensive increase in business activities and prices, which sometimes allows one to predict a crisis in advance. ${ }^{4}$ According to Tugan-Baranovsky (2008 [1913]: 294), Juglar successfully coped with this task on a number of occasions.

\footnotetext{
${ }^{1}$ Many economists maintain that business cycles are quite regular with the characteristic period of 7-11 years. However, some suggest that economic cycles are irregular (see, e.g., Fischer et al. 1988). As we suppose, comparative regularity of business cycles is observed rather at the World System scale than in every country taken separately. This corroborates the important role of exogenous factors for the rise and progress of business cycles (for more details see below).

${ }^{2}$ Medium-term cycles (7-11 years) were first named after Juglar in works by Joseph Schumpeter, who developed the typology of different-length business-cycles (Schumpeter 1939, 1954; see also Kwasnicki 2008).

${ }^{3}$ Notwithstanding the belief of some influential modern economists in the contrary (see, e.g., Zarnowitz 1985: 544-568; Mankiw 2008: 740).

${ }^{4}$ It is worth mentioning here that, before Juglar, prevailing views were based on Adam Smith's ideas of 'invisible hand' and on Say's law of markets. According to such views, equilibrium state is considered to be the main one for the market, various shifts from it being caused by some external factors. Consequently, crises are also caused by random factors. However, currently these ideas (those of external shocks) are rather popular again. We will consider this issue in more detail further on.
} 
A few notes on Juglar cycles (which will be also denoted as J-cycles below). Let us turn to a brief description by Tugan-Baranovsky of the economic cycle scheme proposed by Juglar:

\begin{abstract}
'Industrial crisis never comes unexpectedly: it is always preceded by a special heated state of industry and trade whose symptoms are so specific that an industrial crisis may be forecasted in advance... What causes these regular changes of booms and busts? Juglar indicates one main cause: periodic fluctuations of commodity prices. The prosperous epoch that precedes the crisis is always characterized by the growth of prices: "Annual savings of civilized nations (that enlarge their wealth) also lead and sustain the constant growth of prices: this is a natural state of the market, a prosperous period. The crisis approaches when the upward movement slows down; the crisis starts when it stops... The main cause (one may even say - the only cause) of the crises is the interruption of the growth of prices" (Juglar 1889: 33). The overall mechanism of the crisis development is specified by Juglar in the following way. The increase in commodity prices naturally tends to impede the sales of respective commodities. That is why with the growth of prices the foreign trade balance becomes less and less favorable for the respective country. The gold starts to move abroad to pay for the imports whose amounts start to exceed those of exports. At the beginning the amounts of gold moving abroad are negligible and nobody pays attention to this. However, the higher the prices, the greater the amount of gold that moves abroad. Finally, the commodity prices reach such a high level that selling the respective goods abroad becomes highly problematic. As the traders cannot cover the import expenses with the export revenues, they have to renew their promissory notes in banks after the payment deadline, and this accounts for the intensification of the discounting operations of the banks in the period that directly precedes the crisis. Yet, the payments cannot be delayed forever; sooner or later they should be made. The commodity prices fall immediately, this is followed by bankruptcies of banks and traders, and the industrial crisis begins' (TuganBaranovsky 2008 [1913]: 294-295).
\end{abstract}

It can be seen that the central mechanism of cyclical fluctuations, in Juglar's opinion, is the fluctuation of prices, their increase leading to recovery and upswing, their decrease being followed by crisis and depression. The exceptionally important role of price fluctuations is indisputable; it has been noticed by economists belonging to various schools (see, e.g., Haberler 1964 [1937]). Among them one can mention such contemporaries of Juglar as Karl Marx and Friedrich Engels. In Tugan-Baranovsky's opinion (Tugan-Baranovsky 2008 [1913]), with which we are ready to agree, Juglar's theory, however, does not explain adequately enough the main point, namely the increase in commodity prices in the period that precedes the crisis. Subsequent researchers described numerous mechanisms of such an increase, ranging from interest rate fluctuation, credit expansion and reinvestment to the behavior of aggregate demand and aggregate supply curves, as well as psychological factors such as ungrounded optimism. Nevertheless, 
the issue is still subject to vigorous academic discussions. Tugan-Baranovsky himself suggests that crises are caused by a lack of capital, as in the upswing period capital is spent faster than it is accumulated. As a result, both credit and impulse to development are exhausted, while structural disproportions lead to crisis phenomena (not necessarily in the form of an acute crisis; he was right in stating that the crisis intensity depends on the intensity of upswing). Tugan-Baranovsky emphasizes (and we would agree with him on this point to a certain degree) that the school of Marx and Engels suggested the deepest understanding of crisis for their time. According to them, crises are caused by over-production (which is a consequence of the main contradiction of capitalism). Overproduction itself is stipulated, first of all, by the anarchic character of capitalist production; secondly, by poverty of the masses, their exploitation, and the tendency of salaries to decrease. As a consequence of constant growth of capital's organic structure (i.e. the decline of the proportion of salaries in total production expenses), according to Marx, the profit rate falls. ${ }^{5}$ Capitalists try to overcome the profit rate reduction by introducing new machines, which leads to labor productivity growth. This leads to the expansion of the commodities' supply and, consequently, to their overproduction (because of the 'anarchy' of capitalistic production). Then crisis is the explosion of contradictions of capitalistic production, and, consequently, the restoration of equilibrium. Some Marxist economists provided fundamental descriptions of the history of crises (see, e.g., Mendelson 1959-1964; Varga 1937; Trakhtenberg 1963 [1939]). However, Marx and Engels, in our view, did not manage to show the true connection between processes of production and circulation (the latter were ignored as an allegedly less fundamental part). Thus, they were not capable of revealing the causes of the explosiveness of crises and dramatic changes at so-called turning points (i.e., from boom to acute crisis and from bust to recovery and boom).

In the first half of the $20^{\text {th }}$ century, numerous theories explaining economic cycles were already present. In fact, the under-consumption theory was one of the oldest, emerging a long time ago (actually, together with the science of political economy itself). Among its earliest followers, Lord James Lauderdale, Thomas Malthus and Jean Sismondi were the most prominent. In the first half of the $20^{\text {th }}$ century, a significant contribution to scientific re-consideration and diffusion of the under-consumption theory was made by John Atkinson Hobson, William Foster, Waddill Catchings, Emil Lederer. Essentially concordant with its ideas were some of the abovementioned approaches of the Marxist orthodox school, which assumed that the conditions of the working class, according to the law of absolute impoverishment put forward by Marx, must worsen. ${ }^{6}$

\footnotetext{
${ }^{5}$ Phenomenon marked by economists of various schools but explained differently.

${ }^{6}$ However, such explanation has become an anachronism long ago. The given theory correlates very badly indeed with a long-term trend to an unprecedentedly fast (against the general historical background) increase in life standards (and real incomes) of 'direct producers' in general, and the 'working class' in particular. This trend is rather typical for 'capitalist' countries and is observed in reality.
} 
Monetary theories saw causes of cyclicity mainly in the cumulative character of the expansion and contraction of business activities depending on the available amounts of money in the economy. ${ }^{7}$ The most vivid example is Hawtrey's theory (see, e.g., Hawtrey 1926, 1928). For him, trade-industrial crises appeared to be purely monetary phenomena, as, in his opinion, the changes of monetary flow suffice to explain the transitions from upswings to depressions (and vice versa). On the whole, undoubtedly, the monetary component of cyclicity and crises is very important. However, representatives of monetary theories attributed a too dominant role to monetary factors, thus ignoring non-monetary causes.

One of the versions of the theory of over-accumulation is based on the ideas of Tugan-Baranovsky. Haberler (1964 [1937]) divides representatives of the theory into followers of its monetary and non-monetary versions. The first group includes those economists who suggest that monetary factors, acquiring great importance with credit expansion, cause strong disproportions between those economic sectors producing consumer goods and those producing capital goods (or, more exactly, between the sectors of the manufacturing chain). The followers of this version of the theory have made a particularly valuable contribution to the analysis of disproportions in production structure caused by the credit expansion during the phase of boom and prosperity, as well as to the interpretation of crisis as a result of those disproportions. Representatives of this direction include Friedrich von Hayek, Fritz Machlup, Lionel Robbins, Wilhelm Roepke, and Richard von Strigl. Numerous representatives of this direction belong to the so-called Austrian School, which started from the works by Ludwig von Mises (1981 [1912], 2005). The representatives of the Austrian School see the most important cause of crises in state interference into economic processes, particularly the artificial credit expansion. Special attention is given to the role of central banks as mechanisms generating crises (see, e.g., Huerta de Soto 2006; Skousen 1993; Rothbard 1969; Shostak 2002; Kuryaev 2005). ${ }^{8}$

The other, non-monetary direction of over-accumulation theory is represented by the authors whose theories are based on taking non-monetary factors into account: inventions, discoveries, creation of new markets, etc., that is the factors securing favorable conditions for new investments. This direction is represented by Gustav Cassel, Peter Hansen, Arthur Spiethoff, and Knut Wicksell. Works

\footnotetext{
${ }^{7}$ It should be noted that, from the point of view of General Systems Theory, this point is essentially related to the issue of positive feedback loops, which will be considered in more detail further on. The action of these feedbacks can lead to phenomena perceived as 'booms', 'collapses', and 'breakdowns' (see, e.g., Sornette 2003).

${ }^{8}$ As a separate direction, a group of economists may be specified who developed the so-called 'acceleration principle'. According to this principle, the changes in consumer goods production cause, due to technological reasons, much sharper fluctuations in production goods sector, as investments into main capital require much more time and expenses. This causes a general demand increase, which eventually turns out to be greater than required for optimal development, which creates prerequisites for crisis origin (see, e.g., Haberler 1964 [1937]).
} 
by Arthur Pigou and Joseph Schumpeter are also essentially close to this direction.

Psychological theories are also worth mentioning. Even though every economic phenomenon has its psychological aspect, some theories (not without reason) when interpreting different cycle phases assign a special importance to 'psychological reaction' that can considerably increase disproportions, make a new phase occur faster or slower, contribute to business activity increase or hinder it, etc. Among the representatives of psychological theory, one may mention such prominent economists as, for example, John Keynes, Frederick Lavington, Arthur Pigou, and Frank Taussig. In some aspects they ascribe to psychological factors (such as optimism, pessimism, euphoria, panic) a relatively independent impact (for more details see Grinin 2009c).

Theories of economic crises can be classified in a variety of ways. For example, they can be segregated into exogenous and endogenous ones (see, e.g., Morgan 1991), which is closely connected with approaches to the explanation of the nature of an equilibrium in economy. We take it as a basis that, though cyclicity has an endogenous structure being connected to occurrence of structural disproportions, yet crises cannot occur without some exogenous impacts. Essentially, the economy of a given country cannot be regarded in an isolated way, as the economic field is always much broader than the one of an isolated economy. It serves as part of the World System economic field, so in reality external impacts must necessarily be observed (see for more details Grinin and Korotayev 2012). The following important aspect must also be taken into consideration: while crisis in a given country may have first of all an endogenous character, its process and characteristics may possess substantial peculiarities in comparison to crisis in countries where it is caused by exogenous factors. In particular, under modern conditions many countries - as for example, China, India, or Russia - have not exhausted their resources for development. Crisis in these countries occurred just under the influence of a sharp change of external conditions. And, as external conditions of every country form a unique combination, crisis would have important peculiarities in each particular case. At the same time, in the USA the crisis was more of endogenous character, as the country's economic resources had been worn out to a greater extent than that in many developing countries. Such a situation is generally (though, of course, not always) typical for the development of crises in the core of the World System, on the one hand, and in its periphery, on the other. In the center, crises have a more endogenous character, while in the periphery their origins are usually more exogenous, as they tend to be caused by economic fluctuations in the center (Grinin and Korotayev 2010a, 2010b). Thus, every crisis has always both endogenous and exogenous causes, but their combination is specific for each particular society in every particular period, which makes the situation unique for any society and any crisis. 
Kondratieff (2002: 11-14) divided all approaches firstly into ones regarding economic phenomena as static, considering static equilibrium state in economy as basic, and all deviations from such equilibrium as disturbances. Among the followers of this approach Kondratieff named William Jevons, Leon Walras, Vilfredo Pareto, Gregory Clark, Alfred Marshall, Knut Wicksell, etc. Secondly, in Kondratieff's view, the researches of some other economists were oriented mostly at the study of economic dynamics. These economists state that the equilibrium is not a basic condition; they may even consider it as random, whereas, according to them, the economic dynamics go through a whole range of regular development phases. Among those economists Kondratieff mentions Karl Marx, Clement Juglar, Mikhail Tugan-Baranovsky, Arthur Spiethoff, Jean Lescure, Albert Aftalion, and George Mitchell. He indicates, however, that these researchers elaborated on particular problems of economic dynamics, their works stand somewhat apart from the general development of economic theory. Nevertheless, it should be added that these researchers made an especially important contribution to the development of the economic cycle theory.

As regards the above-mentioned division, it should be noted that, in the view of some economists, the essence of Keynesian Revolution is in Keynes' ideas (1978 [1936]) destroying the belief in perfect inner regulatory forces of market mechanisms (Adam Smith's 'invisible hand' [see Smith 1935]), which meant the true end of the laissez-faire doctrine (see, e.g., Blaug 1985). The discussions between the Keynesians and Neoclassicists are mainly centered on the question whether economy possesses self-regulating forces. ${ }^{9}$ Classical theory pays particular attention to long-term economic growth, dwarfing the meaning of economic cycles. Keynesians insist that crisis-less economy growth is only possible in the presence of adequate monetary and fiscal policies playing the role of countercyclical stabilizers. In other words, Keynesians maintain that economic growth directly depends on the state's economic policy, without which such growth may not occur altogether. As Samuelson and Nordhaus note (Samuelson and Nordhaus 2009a: 486-487), in Keynesians' opinion, the economy is prone to lengthy periods of recurring unemployment followed by speculation and increasing inflation. While for a classical economist the economy is similar to a person leading a healthy way of life, for a Keynesian, economy is a manicdepressive personality, periodically inclined either to boundless rage and groundless gaiety, or to hopeless sullenness.

Since the 1950s, but especially from the 1970s to the 1990s, discussions concerning problems of cyclicity were connected with choosing the parameters through which economists proposed to influence it in order to diminish the negative consequences of uneven economic development. Expansion and de-

\footnotetext{
${ }^{9}$ In classical economic theory, self-regulating forces are stated to be ones connected with the behavior of economic agents: entrepreneurs, workers, buyers, sellers, etc., stipulated by elasticity of salaries and prices, which are capable of supporting the economy in a state of full employment.
} 
velopment of the Keynesian theory contributed to the advancement of the idea about the economy's immanent proneness to falls and booms (i.e., to cycles). However, on the other hand, the popularity of the idea about the possibility of influencing cycles through state policy led to the economic thought focusing mainly on the ways of producing such an influence. The problems of the cycles' nature and their deep causes gradually shifted to the periphery of the economic science.

Best-known in modern economic thought are the Keynesian (more exactly, neo-Keynesian) and monetary schools. The first post-war decades showed that the state policy of influencing economic parameters (such as aggregate demand, aggregate supply, discount rates, etc.) is not entirely successful. First of all, it is not always effective; secondly, it is not always based on long-term economic interests; thirdly, it has a certain lag, as necessary laws and decisions must be subject to a long procedure of coordination, approval, and enforcement. This led to growing popularity of the monetarist theory, which suggests that the state should exercise less direct influence on economy, while its interference must be more subtle and concentrate mainly on regulating money supply, money circulation velocity, state debt volume, and interest rates. ${ }^{10}$ An important contribution of this school to the macroeconomic theory can be seen in developing the idea about the necessity of following the rules of money circulation and not relying on voluntary fiscal and monetary policy.

Thus, the main difference between the views of Keynesians and monetarists lies in their approaches to defining aggregate demand. Keynesians suggest that aggregate demand changes are influenced by numerous factors, while monetarists believe the main factor having impact on output and prices is the change of money supply. Monetarists believe that the private sector is stable, and state interference often simply extracts resources; macroeconomic fluctuations appear mainly because of fluctuations of money supply. In general, one can observe different views as regards the questions of which instruments should be used to influence the cyclicity, and what should be the role and economic policy of a state in short-term and long-term perspectives.

However, some more radical views on direct state interference into the economy are also present within the neoclassical theory. One of its tenets is based on the so-called theory of rational expectations (Robert Emerson Lukas and others), which essentially suggests that, as people use all available information, they can figure out in advance the predictable state policy and use it for their own benefit, as a result of which state policy turns out ineffective. Rough-

\footnotetext{
${ }^{10}$ It is no coincidence that dominating positions in global economic science (and practice) went from Keynesians to monetarists in the early 1970s at a transition period from upswing to a downswing phase of the $4^{\text {th }}$ Kondratieff cycle. On the other hand, such position transition was stipulated by refusal from attachment to the gold standard in dollar, which led to great changes in behaviour of finances devoid of such an anchor.
} 
ly speaking, 'no government can outwit the taxpayers'. Neoclassicists also assume price and salary flexibility (that is why the theory is called neoclassical, as, similar to the classical pre-Keynesian one, it is based on the idea of economy self-regulation). Like monetarists, they suppose that state influence should concentrate mainly on indirect economy regulation via various monetary instruments.

However, it is important to understand that in the last 10-15 years the process of definite and substantial synthesis of old and new economic theories has been going on (for more details see Samuelson and Nordhaus 2009a: 505507). ${ }^{11}$ In particular, economists started paying more attention to expectations, as neoclassical theory suggests.

\section{Phases of Medium-Term Cycles of Juglar (J-cycles)}

Some modern economists single out only two main phases of the business cycle: upswing and downswing (there are some other names for those phases e.g., 'expansion' and 'contraction', whereas moments corresponding to the crisis (emerging at the peak of the overheating) and the trough of the downswing/recession are interpreted as inflection points (see, e.g., Samuelson and Nordhaus 2009b). ${ }^{12}$

However, it is not rare that the cycle is subdivided into four phases ${ }^{13}$ (and we prefer to do this within our model). For more details on our model of the Juglar cycle see Grinin, Korotayev, and Malkov 2010. ${ }^{14}$

Thus, in our model J-cycle consists of four phases:

- recovery phase (which we could subdivide into the start sub-phase and the acceleration sub-phase);

- upswing/prosperity/expansion phase (which we subdivide into the growth sub-phase and the boom/overheating sub-phase);

\footnotetext{
${ }^{11}$ Actual synthesis of Keynesian and monetary theories started much earlier.

${ }^{12}$ Yet, generally speaking, the number of phases may depend on how detailed the respective analysis is (as well as a number of other factors). Thus (see below), we subdivide each cycle into four big phases (basing ourselves on Schumpeter's approach to the distribution of cycle phases), and then single out eight subphases (two subphases per every phase), whereas Burns and Mitchell (1946) only identify two big phases (expansion and contraction) subdividing each phase into three subphases, and consider turning points (peak and trough) as separate short phases. Thus, they get eight stages too (as the ninth stage belongs actually to the next cycle).

${ }^{13}$ On the other hand, it appears possible to single out two sub-phases in each phase.

14 This model takes into account a number of approaches to the analysis of such cycles that are specified in the publications by Juglar (1862, 1889); Lescure (1907); Marx (1961 [1893, 1894]); Tugan-Baranovsky (1954, 2008 [1913]); Hilferding (1981 [1910]); Mitchell (1927), Keynes (1978 [1936]); Varga (1937); Haberler (1964 [1937]); Mendelson (1959-1964); Minsky (1983, 1985, 1986, 2005); Hicks (1946 [1939], 1993: 432-442); Samuelson and Nordhaus (2005: 403552); Schumpeter (1939); von Hayek (1931, 1933); von Mises (1981 [1912], 2005); Cassel (1925); Pigou (1929); Friedman (2002); Abel and Bernanke (2008a), as well as a number of other economists.
} 
- recession phase (within which we single out the crash/bust/acute crisis sub-phase and the downswing sub-phase);

- depression/stagnation phase (which we could subdivide into the stabilization sub-phase and the breakthrough sub-phase).

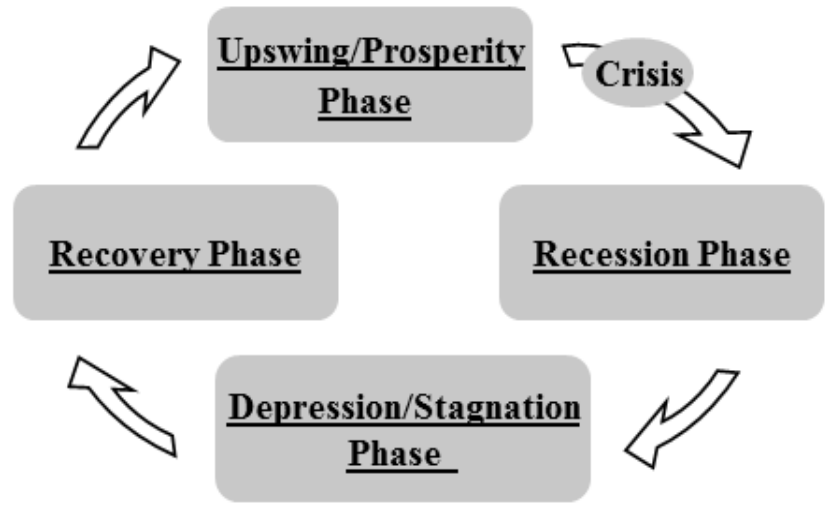

Fig. 1. The Model of a Juglar Cycle

Recovery phase starts after (and as a result of) the liquidation of disproportions (and the establishment of new proportions) that almost inevitably take place during preceding phases of recession and stagnation (which often lead to a significant restructuration). That is why a new cycle starts at a new level of equilibrium (Schumpeter 1939). The recovery and certain growth can start because, as a result of the preceding downswing, excessive commodity inventories have been dissolved and have come into correspondence with extant demand, some unsatisfied demand for commodities has been formed, problematic firms have disappeared, bad debts and fictive capitals have been 'burnt out', businessmen have become much more cautious (see, e.g., Minsky 1983, 1985, 1986, 2005), etc.

During the expansion phase the growth accelerates, whereas the recovery becomes general. The active expansion often needs some external factor (e.g., the emergence of some major new market). The demand for resources and commodities grows, investments increase in a really substantial way. This tends to lead to the growth of prices. The demand for credit also grows, new enterprises emerge, active speculations at stock and commodity exchanges take place. If the growth continues and becomes very fast, the economy moves to the boom (overheating) sub-phase, which leads to overstraining of the financial markets, as free liquidity is absent. As a result, prices grow very fast, 'bubbles' emerge, speculation increases.

Recession phase. Finally, some factors interfere (e.g., a sudden drop of demand or prices, a bankruptcy of a large firm, a default of some foreign state, 
additional demand for funds in the context of worsening political situations, a new law that changes 'rules of the game'); as a result one observes bust and acute crisis. This is accompanied by the decline of industrial production, waves of bankruptcies, decline of orders for various products, shut-down of many enterprises, explosive growth of unemployment, and so on.

Depression phases are the periods of stagnation and very slow economic growth, when the economy moves from the overheating and bust, the overaccumulated inventories are dissolved, prices decrease (though in modern times prices may behave in a somehow different way during this phase). The depression is the process through which the market economy gets adapted, it gets rid of extremes and distortions of the previous inflationary boom and restores a stable economic state. Within this perspective, depression turns out to be an unpleasant but necessary reaction to distortions and extremes of the preceding boom (e.g., Rothbard 1969).

The causes of cyclical crises. Economic crisis (bust, recession, and depression) is the most dramatic part of the medium-term J-cycle. The crisis is always a result of the preceding active growth, because this growth inevitably produces structural strains not only in the economy, but in the society as a whole (as the current social institutions are 'designed' for a certain scale of phenomena and processes). However, notwithstanding all the similarities, every crisis, naturally, has certain unique features.

The characteristic features of classical J-cycles can be presented as follows: at the expansion phase they were characterized by very fast (sometimes even explosive) growth (boom) that involved a tremendous strain within the economic system, which was followed by an even more impressive bust.

The phase of expansion (that included the sub-phase of boom and overheating) was accompanied by the following phenomena:

a) a very strong (even inadequate) growth of prices of raw materials and real estate;

b) excessive demand for credit and the expansion of the investment over any reasonable limits;

c) outbreak of speculations with commodities and bonds;

d) enormous growth of risky operations.

All these are salient features of the Juglar cycle that have been described on many occasions by representatives of various schools of the economic thought. On the other hand, they can be easily found in the recent global economic crisis.

Our analysis has also demonstrated that during the expansion phase a special role is usually played by some new financial technology or some new type of financial assets.

Sharp transitions from booms to busts were connected with a spontaneous economic development that was regulated by almost nothing except the market forces, as the state interference in the economic development was not sufficient. 
Within such a context (and taking into consideration the presence of the gold standard) acute crises became inevitable. ${ }^{15}$

\section{On the Importance of Further Research on the Theory of J-Cycles}

After the Great Depression the interest in Juglar cycles grew sharply, and, according to Haberler (2008: 431), there was no other period in the history of economic thought when the problems of economic cycles were studied so intensively. However, later, in the second half of the $20^{\text {th }}$ century (especially, during Phase A of the $4^{\text {th }}$ Kondratieff Cycle), the dynamics of business cycles experienced a significant change (first of all as a result of the active interference of the state into the economic life) ${ }^{16}$, recessions became less deep than before (whereas the crisis became less dramatic), the recovery came relatively fast, etc. As a result, economists began paying more attention to long waves of business activities (Kondratieff cycles) than to Juglar cycles, though, mostly by tradition, macroeconomics textbooks still tend to include a chapter on those cycles (yet, they are mostly denoted just as 'business cycles'). ${ }^{17}$ We believe that such neglect with respect to the study of J-cycles is unproductive. In our opinion, modern crisis is quite similar in type to classical Juglar's cycle crisis.

The cyclical dynamics of Juglar type in their most pronounced form (that is, not smoothed by state intervention) was determined by the following factors: a) the presence of the gold standard in transactions within a country, as well as at the international level; b) uncontrolled dynamics of prices and interest rates; c) relatively weak interference of the state during upswings and even crises and recessions (though gradually such interference increased). These resulted in fast (sometimes even explosive) upswings (that demanded a great tension on the part of the economic system) and equally rapid downswings. The upswing, boom and overheating were accompanied by rapid and inadequate growth of prices of raw materials and real estate; an increase in intensity of speculations with commodities and stock assets; by a dramatic expansion of credit and risky operations; and the growth of investments beyond any reasonable limits. All

\footnotetext{
${ }^{15}$ Thus, with the excessive growth of credit and swelling of financial assets, the amount of money substitutes (shares, bills, bonds, etc.) greatly increased. As a result, with a decrease in confidence in these securities a sudden demand for gold and cash increased so much that destroyed the entire banking system.

${ }^{16}$ Even some Soviet economists had to acknowledge this, e.g., Varga, a Hungarian by origin, who was influenced originally by the Austrian Economic School (e.g., Varga 1974: 366-400). In particular, he noticed that the depression phase had contracted in a very significant way. The change in crisis patterns in England since the late $19^{\text {th }}$ century was first noticed by Tugan-Baranovsky (2008 [1913]). Mitchell also showed that, though recession is a necessary part of the cycle, not every cycle should be necessarily connected with an acute crisis (Mitchell 1930: 391-392). For a more detailed analysis of post-war cycles see Grinin and Korotayev 2012.

${ }^{17}$ See, e.g., Mankiw 1994: ch. 14; Sacks and Larren 1996: ch. 17; Abel and Bernanke 2008a: ch. 8, even though such chapters are present not in all textbooks of the kind. For example, in the textbook by Dornbusch and Fischer (1997) such a chapter is absent.
} 
these are salient features of the J-cycles that were described many times in the writings of representatives of various schools of economic thought (see, e.g., Juglar 1862, 1889; Marx 1960 [1867]; Mills 1868; Lescure (1908); TuganBaranovsky 1954; Marx 1961 [1893, 1894]; Hilferding 1981 [1910]; Haberler 1964; Keynes 1978 [1936]; Hicks 1946 [1939]; Abel and Bernanke 2008; Samuelson and Nordhaus 2005, 2009b).

Such an expansion of assets tended to lift temporarily limitations produced by the metallic standard. This is the reason for the fact that we observe almost always during the upswing phase the effect of some new financial technology (naturally, in addition to the old ones), or some new type of assets (e.g., in the $19^{\text {th }}$ century this could be railway shares), that could drive the credit and speculations, amplifying the overheating of the economic system. ${ }^{18}$ The monetary component of the Juglar cycles was always exceptionally important (though this was the dynamics of real economy that was at the basis of cyclical upswings).

The above indicated factors were the main ones to engender very sharp and vividly expressed cyclic features. However, gradually under the impact of the Keynesian recipes (in the framework of national economic development) it became possible to minimize these dramatic distortions of rises and falls and to put speculation under a certain control (e.g., after the Great Depression in the USA the Glass-Steagall Act was passed, forbidding banks, investment firms and insurance companies to speculate at stock exchanges [see Lan 1976; Samuelson and Nordhaus 2005, 2009b; Suetin 2009: 41]). This led to smoothing of cyclical fluctuations and to less explosive crises. ${ }^{19}$

However, currently, the crisis has evidently overgrown national borders, occurring namely as an international crisis, where national norms act in an obviously weakened form, while international regulations have not yet been worked out. That is why a number of old features recur at the new stage, because the methods of regulation applicable to separate countries would not work at World System scale, still more so that the rules of such regulation have not been worked out yet.

We suggest that the current recurrence of some features of Juglar's cycle is connected namely with the following features of anarchy and arrhythmia of the non-regulated market economy:

\footnotetext{
${ }^{18}$ For example, by the Charter of the Bank of England (as renewed in 1833), it was permissible to establish deposit joint stock banks everywhere. As a result, their number started growing rapidly which greatly contributed to the growth of capital accumulation, speculation, and at the same time to the accumulation of conditions for the 1836 crisis (for more detail see Tugan-Baranovsky 2008 [1913]: 110-111). For more detail on the development of various new financial technologies from cycle to cycle see Grinin and Korotayev 2012.

${ }^{19}$ In 1999 in the USA the law on financial services modernization was passed, which annulled the Glass-Steagall Act that was in force for more than 60 years (see Suetin 2009: 41). As a basis for introducing the law on financial services modernization, it has been claimed that American credit organizations are inferior to foreign rivals, especially European and Japanese 'universal banks' which were not subject to such limitations (Grinspen 2009: 200).
} 
1. Subjects of international law (and their economic agents) largely behave the same way as subjects of national law and the market previously did. As they use foreign currency and foreign currency rates in their dealings, this invariably leads to sharp distortions in international trade, devaluations, etc.

2. In the last decades capital movement between countries became free, that is it is relatively weakly regulated by national law and almost not regulated at all by international law. This causes huge and exceedingly fast capital movements, which lead to a very rapid growth in some places and then to a sharp decline and corresponding crisis phenomena.

3. In the modern economy not only new financial technologies have been developed, but the modern economy itself largely started producing values namely in the financial sphere (financial services). Thus, the financial component of crisis has increased dramatically; this differs from previous decades, when the main growth went on in the sphere of manufacturing. These processes are analyzed in greater detail in the following publications: Grinin 2009a, 2009b; Grinin and Korotayev 2012; Grinin, Malkov, and Korotayev 2009.

We would like to conclude the present section with the following important note. Activities of modern financial corporations and funds lead to an uncontrollable growth of financial assets and anarchy in their movements; that is why it is criticized quite convincingly by various authors (e.g., Schäfer 2009: 279280), including ourselves (Grinin 2009a, 2009c, 2009d, 2012; Grinin and Korotayev 2010a, 2010b; Grinin, Malkov, and Korotayev 2010; Grinin, Korotayev, and Malkov 2010; Akaev, Fomin, Tsirel, and Korotayev 2010; Akaev, Sadovnichy, and Korotayev 2011, 2012). That is why we are absolutely convinced of the necessity to look for ways to minimize the respective risks at the global scale, to regulate activities of financial actors, and to restrict them in their most risky operations (Ibid.). However, it is highly erroneous to claim that the modern financial technologies are immanently destructive, that they only lead the world economy to various calamities, that they are only useful to parasitic financers and speculators. Contrary to this, the modern financial sector performs a lot of generally useful important functions at the global scale. Our own analysis has demonstrated quite convincingly that the global financial system, notwithstanding all its negative points, still performs certain important positive functions including the 'insurance' of social guaranties on a global scale (Grinin 2009d, 2010b, 2012; Grinin and Korotayev 2010a).

\section{Correlation between K-Waves and J-Cycles}

\section{Preliminary Discussion}

\section{Introductory Notes}

The main goal of this section is to study the interaction between $\mathrm{K}$-waves and J-cycles. We believe that the analysis of this interaction may help to clarify significantly both the causes of the alternation of upswing and downswing phases in the K-waves and the relative stability of their characteristic period. 
We have already noticed above that there are numerous explanations as regards the origins of the medium-term Juglar cycles with their characteristic period between 7 and 11 years, ${ }^{20}$ however, there is a substantial degree of unanimity as regards the main factors that are responsible for the emergence of the Juglar fluctuations (though this unanimity is absent as regards the contribution of each of those factors). There is much less clarity and unanimity as regards the causes of the emergence and recurrence of the K-waves (long cycles), as this field is still mostly dominated by various hypotheses (see, e.g., Korotayev and Grinin 2012a). ${ }^{21}$

Notwithstanding substantial advances in the study of wave-like periodic fluctuations, there is no unanimity among researchers as regards many important points (see, e.g., Goldstein 1988 for a review of earlier literature on this subject, or Korotayev and Grinin 2012a); those points include the total number of attested Kondratieff cycles; their periodization (this includes the issue of the presence/absence of the K-waves before the industrial revolution of the $18^{\text {th }}$ century); ${ }^{22}$ which parameters should be used to trace periodic fluctuations; which spheres are subject to those fluctuations (whether they are observed in the economic subsystem only, or also in political and cultural spheres). ${ }^{23}$ There is no unanimity either as regards the issue of the main factors affecting the formation of the waves and the change of their phases $^{24}$ (for more details see Grinin, Devezas, and Korotayev 2012).

Notwithstanding the abovementioned difficulties, we may base our further research on the fact that the K-wave dynamics was actually observed at least during the last two centuries; that we do observe some fairly periodic fluctuations of some important economic indicators (technological innovations, prices, GDP, trade turnover, etc. (see, e.g., Korotayev and Tsirel 2010a, 2010b, 2010c;

${ }^{20}$ See, e.g., Juglar 1862, 1889; Lescure 1908; Marx 1961 [1893, 1894]; Tugan-Baranovsky 1954, 2008 [1913]; Hilferding 1922; Mitchell 1930; Keynes 1978 [1936]; Varga 1937; Trakhtenberg 1963; Haberler 1964 [1937], 2008; Mendelson 1959-1964; Minsky 1983, 1985, 1986, 2005; Hicks 1993: 432-442; Samuelson and Nordhaus 2009a; Samuelson 1994; Schumpeter 1939, 1982; von Hayek 1931, 1933; von Mises 1981 [1912], 2005; Cassel 1925; Pigou 1929; Fridman 2002; Abel and Bernanke 2008a: 361-502.

${ }^{21}$ Some of those hypotheses even suggest climatic change as the main factor generating the K-waves (see, e.g., Mougy 1992).

${ }^{22}$ For the evidence supporting the existence of the preindustrial K-waves see, e.g., Goldstein 1988; Modelski 2006, 2008a, 2008b, 2012; Modelski and Thompson 1992, 1996; Modelski, Thompson, and Devezas 2008; Mougy 1992; Pantin 1996; Pantin and Lapkin 2006, etc. Some scholars, while not rejecting some long-term fluctuations in the pre-industrial period, consider the K-waves in this period as certain historical excesses produced by various exogenous factors (see, e.g., Maevsky 1992: 60).

${ }^{23}$ See an incomplete list of such problems in the following publications: Maevsky 1992: 58-60; Avramov 1992: 64-66; Rumyantseva 2003: 11-12.

${ }^{24}$ As regards the underlying causes, one can identify mono-causal and multi-causal approaches; the latter with more or less success can be combined into one or another paradigm synthesis. About the criticism of mono-causal approaches see, e.g., Rumyantseva 2003: 50. 
Korotayev, Zinkina, and Bogevolnov 2011; Berry and Dean 2012; Devezas 2012; Helenius 2012; Husson and Louca 2012; Korotayev and Grinin 2012a; Modelski 2012; Ternyik 2012; Thompson 2012; Grinin, Korotayev, and Tsirel 2011).

We believe that one of the most promising directions of the K-wave research is constituted by the analysis of the connections between the K-wave and J-cycle dynamics. It appears a bit strange that the relations between $\mathrm{K}$-waves and J-cycles have not been studied sufficiently yet, which indicates that the importance of this relationship is still underestimated. ${ }^{25}$

The relationship between K-waves and J-cycles is visible rather saliently in the point that the most widely accepted dates of the Kondratieff waves and their phases are tightly connected with the most widely accepted dates of Juglar cycles. However, even this aspect of the relationship between Kondratieff and Juglar cycles has been studied rather superfluously and insufficiently (see Poletaev and Saveljeva 1993: 11-12; Avramov 1992: 66-68); note that Kondratieff himself did not pay much attention to this relationship (Kondratieff 2002: 379-380). Schumpeter (1939) paid significantly more attention to this relationship; however, we believe that his view of this relationship was too straightforward; he thought that the structure of long cycles (K-waves) was too similar to the structure of medium-term J-cycles (see also Rumyantseva 2003: 19). Note that Schumpeter, when developing his theory of cycles with different characteristic periods, based himself on the principle of the unity of the cause and the multiplicity of the effects (Avramov 1992: 67); this does not appear to be correct despite some heuristic value of the respective principle. Long-term processes are likely to be caused by factors that are different from the ones causing short-term processes (see, e.g., Korotayev, Malkov, and Khaltourina 2006a: 105111). Below we will demonstrate that the factors generating $\mathrm{K}$-waves are inherent within the expanding reproduction of the economy; however, the shorter-term impulses generating J-cycles produce some ordering of the K-waves.

We believe we need a more profound study of the relationship between two types of cycles. We think that the study of the interaction between J-cycles and $\mathrm{K}$-waves is capable of shedding light on the reasons of the relative stability of the characteristic period of the K-waves and their phases. It does not appear to be possible to explain completely this periodicity with exogenous factors - such as the alteration of technological or population generations. It appears necessary to look for such economic and social processes that are capable to support the abovementioned rhythm. From our point of view, the only real factor that is able to give to the Kondratieff waves the respective rhythm is represented by the Juglar cycles. In addition to the study of the organic links between K-waves and

\footnotetext{
${ }^{25}$ The concept of long waves and the 'normal' business cycle theory exist and develop relatively independently. Experts on the theory of the business cycle with minimal exceptions try to ignore the existence of long waves, and K-wave students make little use of the 'conventional' business cycle theory (Poletaev and Saveljeva 1993: 11-12).
} 
J-cycles, it appears absolutely necessary to research the links between those two types of cycles and certain world-system processes.

\section{Some Preliminary Conclusions}

The analysis of the $\mathrm{K}$-wave manifestation and alteration demonstrates quite convincingly that, notwithstanding a considerable variety of explanations of Kwaves, proponents of all the respective theories are partly right. However, each of those theories has a rather limited field of application. Thus, in order to achieve a more adequate understanding of the nature of the K-waves and their driving forces we need a profound synthesis of various theories. ${ }^{26}$ The situation here is somehow analogous to the one attested in the theory of medium-range cycles. Essentially, proponents of most approaches are right, but the general understanding may only be worked out through a synthetic theory (see, e.g., Haberler 1964 [1937], 2008). Note, by the way, that more theories have been proposed to account for the J-cycles than for K-waves (in particular psychological factors are hardly taken into account in the latter case [for more details on those factors see, e.g., Haberler 1964 [1937], 2008; Grinin 2009d; Grinin, Korotayev, and Malkov 2010], though such factors are very important for an adequate understanding of the alteration of phases of the K-waves).

We have based ourselves on the following approaches to the study of endogenous factors: innovation-based and investment-based, as well as on those approaches that pay most attention to such factors as capital depreciation, decline of profit rates, and the alteration of technological paradigms. We have also taken into account such approaches that pay special attention to exogenous factors: influence of the warfare and the expansion of the external resource base, as well as monetary theories. However, those theories are only used by us within certain limits, determined by our general approaches. It also appears necessary to take into account the point that we only consider K-waves in their economic dimension, ignoring civilization, cultural and other manifestations of the K-waves, but taking into account the full spectrum of factors of the K-wave dynamics (including political, legal, and social factors).

It appears necessary to emphasize again that a very important component of our theory that allows to integrate various approaches is the reliance on the organic link between $\mathrm{K}$-waves and J-cycles.

Below we will present our answers to a few questions that are important with the analysis of K-waves.

1) Are there endogenous factors that generate the alteration of upswings and downswings?

The very alteration of downswings and upswings is connected with the need of the industrial economy to expand; this expansion, however, inevitably

\footnotetext{
${ }^{26}$ Such a task is mentioned from time to time by the $\mathrm{K}$-wave students (see, e.g., Menshikov and Klimenko 1989; Lazurenko 1992).
} 
meets serious obstacles. One may speak about the alteration of two developmental trends: 1) prevalence of qualitative innovations (creation of new technologies); 2) prevalence of quantitative development - implying a wide introduction/diffusion of innovations (see, e.g., Korotayev, Zinkina, and Bogevolnov 2011). Both tendencies are simultaneously present in economic systems; however, in some periods one of these tendencies prevails, whereas in the other periods the other tendency does (see, e.g., Perez 2002, 2010, 2011a, 2011b, 2012; Grinin 2003, 2006a, 2006b, 2006c, 2007a, 2007b, 2007c, 2007d, 2009b, 2012, 2013; Korotayev 2005, 2006, 2007; Korotayev and Grinin 2012a, 2012b; Korotayev, Malkov, and Khaltourina 2006a, 2006b; Grinin and Korotayev 2012). Processes of qualitative innovation are connected with periods of emergence and validation of new technologies of various types (production technologies, financial technologies, social technologies - including technologies of counter-crisis management). Quantitative processes are connected with such periods when such technologies diffuse widely - up to the exhaustion of their potential. For those countries that follow the leaders of the World System, processes of wide diffusion of technologies are virtually equivalent to the process of catch-up modernization (Grinin and Korotayev 2010a, 2010b; Grinin 2013a). At the level of the World System, the analysis of processes of such a modernization (as we will see) may play an important role in the explanation of the length of particular A-phases.

The periods of predominantly qualitative development determine a potential possibility of the B-phase realization, whereas periods of predominantly quantitative development determine a potential possibility of the A-phase realization. Qualitative changes (having shown their advantages) tend to expand/diffuse. After new technologies become habitual, after they come to the level of saturation, they lose their stimulating meaning (see, e.g., Perez 2002, 2010, 2011a, 2011b, 2012; see also Akaev and Rumyantseva et al. 2011); for a new acceleration the global economic system needs a transition from extensive (quantitative) development to a new period of innovative qualitative development. As is well known, this leads not only to the changes of technological paradigms, but also to the changes of financial styles, relationships in the framework of the world trade and so on (see, e.g., Kondratieff 2002; Schumpeter 1939; Menshikov and Klimenko 1989; Lazurenko 1992; Pantin and Lapkin 2006; Rumyantseva 2003; Grinin 2010a; Grinin and Korotayev 2010b; Korotayev, Zinkina, and Bogevolnov 2011).

Thus, prolonged processes of the generation and diffusion of innovation, change of technological paradigms, as well as the models of international relations and economic regulation give long-term impulses toward the acceleration or deceleration of the growth of production, sales, prices, and so on. However, the scheme described above implies only the possibility of alteration of upswings and downswings, but it does not imply that such alteration should be 
regular/periodic. The mechanism that generates a relatively regular periodic temporal rhythm of the phase alteration is established through the alteration J-cycle clusters (see below). Thus, the dynamics of Kondratieff waves is generated by a complex set of various factors and causes that acquire a certain directionality through a synthesis of long-term impulses, J-cycle rhythm, as well as various reactions of economic actors. That is why we cannot agree with Sergey Glaziev who believes that the basis of the K-wave dynamics is created by the life cycles of technological paradigms, whereas 'at the surface of economic phenomena these look as long cycles of economic conjuncture' (Glaziev 2009: 26). This looks as an approach in spirit of Hegel - Marx' set of 'essence and its epiphenomena' that not only strips K-waves of their specificity - it reduces them to one factor only while ignoring a number of such factors that are of no less importance.

As far as exogenous factors (e.g., wars) are concerned, they amplify certain (e.g., inflationary) impulses (that may trigger the process of change). However, it is important to understand that at the level of the World System it does not really make sense to distinguish between endogenous and exogenous factors (except, of course, certain natural [from seismic to cosmic ${ }^{27}$ ] ones). In full extent both K-waves and J-cycles are traced at the World System level. We can hardly find any single society where those waves and cycles are perfectly traced throughout all the 200 years of the industrial development. And if we analyze K-waves at the World System level, then we have to interpret all the relevant social and economic processes as endogenous. In other words, at the World System level we should rather speak about endogenous factors of various orders (except, as has been already mentioned, some natural factors).

2) Which factors do determine a relative temporal stability of the length of K-waves and their A- and B-phases?

The K-waves' length and relative regularity of the alteration of their phases is determined by J-cycle clusters. A-cluster may consist of two to four upswing Jcycles (though most frequently their number is three); B-cluster may consist of two or three downswing J-cycles (though most frequently their number is two). During the K-wave A-phase the fast economic expansion leads inevitably to the necessity of societal change; as a result, B-phase starts. But the possibilities of societal transformation lag behind the demands of the economy, that is why the periods of such a restructuring correspond to periods of more difficult development, that is, to K-wave downswings. Below we will discuss this point in more detail. It makes sense to pay attention to the point that cyclical crises are attributes of medium term crises only.

\footnotetext{
${ }^{27}$ E.g., solar activity.
} 
Clusters of Juglar Cycles and Stable Duration of $\mathbf{K}$-waves and Their Phases

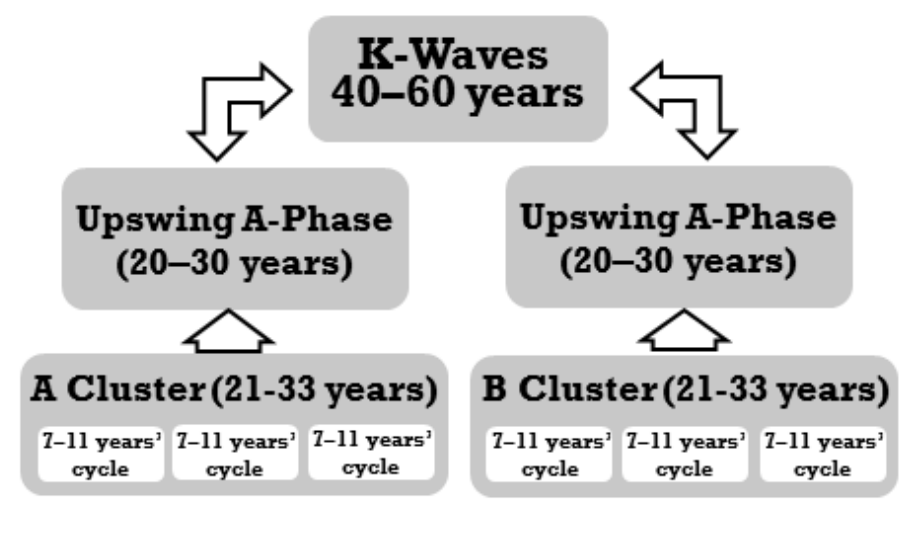

Fig. 2. Clusters of Juglar Cycles

3) Why and how do the main characteristics of the K-wave dynamics change?

This is a result of the development of the world economy, the transition to new conditions, resulting from the transformation of the World System. In the metallic standard epoch, prices were the best K-wave indicators (they are visible there till now when the prices of key commodities expressed in grams of gold [e.g., Grinin, Korotayev, and Tsirel 2011]); later they became more visible in some indicators of economic growth.

4) Which endogenous mechanisms account for the alteration of longterm trends of inflation/deflation?

Those trends are embedded in the nature of industrial economy itself (whereas wars, discoveries of new rich deposits of precious metals and other exogenous factors of this sort may amplify additionally inflationary trends). The trends toward expansion and growth tend to lead to increasing resource limitations and - hence - inflation. However, with metal money, the growth rates of the productivity of labor and potential to produce goods start to outstrip the growth rates of the money mass (effective demand). Money becomes more expensive and profits tend to decrease. This leads to the search for new ways to increase the production, and one of such ways is to reduce costs. The latter leads to the further growth of the volume of the produced goods against the background of the reduction of their prices. Thus, the tendency toward economic expansion generates both the inflationary and deflationary trends. Busi- 
nessmen look actively for the opportunities to increase profit rates and to fight deflation. Such opportunities are usually found (though in no way automatically) through the market expansion (export) and/or the creation/diffusion of new financial technologies. To counteract the deflation effectively a rather wide diffusion of financial technologies is necessary. This increases the monetary mass and - consequently - the effective demand (at the level of both individual societies and the World System as a whole). However, with the exhaustion of the potential of new technologies and territories the deflationary trend strengthens again.

5) Is it possible to speak about the decrease of the characteristic period of the K-waves? And, if yes, what is the mechanism of this decrease?

As has been mentioned above, in the $19^{\text {th }}$ and $20^{\text {th }}$ centuries the characteristic period of the J-cycles decreased from 11 to 7-9 years. This was accompanied by the decrease of the characteristic period of the K-waves from 60 to 4550 years. Thus, some shortening of the K-wave period appears to be observed. However, this change of the length of the K-waves is rather complex (some explanations for this phenomenon will be suggested below).

There are some quite grounded hypotheses regarding a significant shortening of the periods of the $4^{\text {th }}$ and $5^{\text {th }} \mathrm{K}$-waves in comparison with those $\mathrm{K}$-waves that preceded the World War II, suggesting that the lengths of phases and waves depend generally on the speed of reaction of social systems. In the 1970s -1980s in the USA and Europe (especially in the UK) some new radical decisions were made that helped to move faster respective societies from the downswing trough. It appears important to note that in some respects those decisions contributed to the emergence and development of new technologies (and - in particular - financial technologies).

It is important to note that states and other actors spend enormous efforts in order to prolong the prosperous period and to shorten the depressive period. Against this background it is hardly surprising that this is precisely the B-phase (and not the A-phase) of which the length is shortening. We believe that this is a much simpler and more adequate explanation for the shortening of the B-phase of the $4^{\text {th }} \mathrm{K}$-wave in comparison with the explanation proposed by Pantin and Lapkin (2006: 289-303). ${ }^{28}$

\footnotetext{
${ }^{28}$ The gist of their approach is that there are two different types of upward and downward phases of long waves and long waves themselves constitute half of a longer cycle, which consists of two Kondratieff waves and leads to a radical change in technological and institutional foundations of the economy and the international division of labor. According to Pantin and Lapkin, duration of the downswing phase of long waves with the transition from one complete evolutionary cycle to another is reduced by an average of 12 years, while the duration of the upswing phase of Kondratieff waves is kept roughly constant (about 24 years). The very same shortening of evolutionary cycles of world development is due, in their opinion, to the general acceleration of social development. Indeed, one would expect that the acceleration of the rate of development will reduce
} 
6) Is there any relationship between K-waves and warfare?

Before the World War I a certain background of wars was observed during both K-wave phases. However, during A-phases warfare frequency somehow increased due to the intensification of World System modernization processes. The point is that the accelerating modernization generates strains within states and between them, which tends to lead to the increase in warfare frequency.

Explanation of the characteristic periodicity of the J-cycle. Thus, the temporal rhythm of change of $\mathrm{K}$-wave phases is connected with the characteristic period of the J-cycle. But what determines the length of the J-cycle itself?

There are no clear explanations for the period of the Juglar cycle being between 7 and 11 years. We suggest that the minimum and maximum length of the J-cycle stems from rather natural circumstances. If we take a cycle consisting of four phases, even with an average length of each phase around a year, the period of the cycle will be about four years (however, it should be taken into account that each phase consists of at least two sub-phases). Of course, within $\mathrm{K}$-wave A-phases the phases of repression, depression, and recovery may last one year each (whereas the recession may last even less than one year), though depression and recovery phases may last for two and even more years each. On the other hand, the upswing phase of the J-cycle can hardly last for just one year, as a one year long upswing can hardly generate the overheating of the economy.

In order for a downswing to transform into a boom a fast growth should continue for at least three years. The first two years of expansion tend to go on the basis of the engaging of existing capacities as well as the realization of the changes made during the recession and depression. Two years of expansion make businessmen confident that the situation is permanently improving. They begin to invest more actively, the credit expands, the prices of resources start growing. However, in order that the development could reach a limit, beyond which an easy economic growth becomes impossible, a rather significant increase in GDP should be observed, ${ }^{29}$ which needs normally not less than four years even with rather fast growth rates. This time is necessary for the 'bubbles' to form, prices reach record levels and the credit expansion experiences the overloading. In any case, four to five years of expansion ( + threefour years for the other phases) yield together at least seven-nine years. However, in favorable conditions the expansion may continue even seven or eight years. The empirical data on the J-cycle length are discussed further in this article.

the duration of Kondratieff waves, but the logic of these authors is not clear - why does the length of some phases decline? And why do the others remain stable (whereas the shortening should rather be manifested proportionally)?

${ }^{29}$ No less than $30-50 \%$, whereas in emergent markets the growth may be twofold, or even threefold. 


\section{Juglar Cycles as Structural Elements of the K-Waves}

How many J-Cycles do We Find during a K-Wave Phase?

An Analysis of Empirical Data

'Economists use widely modeling on the basis of so-called stylized facts. This is achieved through the simplification of the real situation by abstracting from concrete historical fluctuations, which allows to identify the most significant features in the economic dynamics. Such stylized facts include the statement that the large cycle consists of six mediumrange Juglar cycles. Duration of the industrial cycle of this type almost always (this is also a stylized fact) falls within the range of 7 to 11 years. Accordingly, the total duration of the big cycle can range from 42 to 66 years, which is roughly consistent with observations from the beginning of the industrial revolution in the UK, as well as with the assertion that the average length of a long wave is half a century. It is also argued that a long cycle consists of approximately equal halves: the rising and falling waves of economic conditions. Thus, every half contains three Juglar cycles' (Klinov 2008: 64).

In our verbal model of the relationship between $\mathrm{K}$-waves and J-cycles (as in our spectral analysis [Korotayev and Tsirel 2010a; Grinin, Korotayev, and Tsirel 2011: Ch. 2] and our mathematical model of the J-cycle [Grinin, Malkov, and Korotayev 2010]) we were bound to use stylized facts mentioned by Vilenin Klinov. Now we will try to find out how much those stylized facts correspond to the empirical data. We will pay a special attention to the following 'stylized facts': a) each Kwave consists of six J-cycles; b) the length of the A-phase of each K-wave is equal to the length of its B-phase; c) each A-phase consists of three J-cycles, and each B-phase also consists of three J-cycles.

First, consider the general picture of the correlation between Juglar cycles and Kondratieff waves (see Table 1 and Fig. 3). 
Table 1. Correlation between Juglar cycles and Kondratieff waves (the first version)

\begin{tabular}{|c|c|c|c|}
\hline $\begin{array}{c}\text { Serial } \\
\text { numbers } \\
\text { of } K- \\
\text { waves }\end{array}$ & $\begin{array}{c}\text { Long waves' phases and } \\
\text { their dates }\end{array}$ & $\begin{array}{l}\text { Serial numbers and } \\
\text { dates of J-cycles }\end{array}$ & $\begin{array}{c}\text { Number of J- } \\
\text { cycles per } \\
\text { the respec- } \\
\text { tive K-wave } \\
\text { phase }\end{array}$ \\
\hline \multirow[t]{3}{*}{$I$} & \multirow{3}{*}{$\begin{array}{l}\text { B (downswing): } \\
\text { 1817-1847 }\end{array}$} & $\mathrm{J} 1: 1817-1825$ & \multirow[t]{3}{*}{3} \\
\hline & & J2: $1825-1836 / 7$ & \\
\hline & & J3: 1836/7-1847 & \\
\hline \multirow[t]{5}{*}{$I I$} & \multirow{3}{*}{$\begin{array}{l}\text { A (upswing): } \\
1847-1873\end{array}$} & J4: 1847-1857 & \multirow[t]{3}{*}{3} \\
\hline & & J5: 1857-1866 & \\
\hline & & J6: 1866-1873 & \\
\hline & \multirow{2}{*}{$\begin{array}{l}\text { B (downswing): } \\
\text { 1873-1890/3 }\end{array}$} & J7: 1873-1882 & \multirow[t]{2}{*}{2} \\
\hline & & J8: $1882-1890 / 3$ & \\
\hline \multirow[t]{6}{*}{ III } & \multirow{4}{*}{$\begin{array}{l}\text { A(upswing): } \\
\text { 1890-1929/33 }\end{array}$} & J9: 1890/3-1900/3 & \multirow[t]{4}{*}{4} \\
\hline & & J10: 1900/3-1907 & \\
\hline & & J11: 1907-1920 & \\
\hline & & J12: 1920-1929/33 & \\
\hline & \multirow{2}{*}{$\begin{array}{l}\text { B(downswing): } \\
\text { 1929/33-1948/9 }\end{array}$} & J13: 1929/33-1937/8 & \multirow[t]{2}{*}{2} \\
\hline & & J14: 1937/8-1948/9 & \\
\hline \multirow[t]{4}{*}{$I V$} & \multirow{2}{*}{$\begin{array}{l}\text { A(upswing): } \\
\text { 1948/9-1966/7 }\end{array}$} & J15: 1948/9-1957/8 & \multirow[t]{2}{*}{$2^{30}$} \\
\hline & & J16: 1957/8-1966/7 & \\
\hline & \multirow{2}{*}{$\begin{array}{l}\text { B(downswing): } \\
\text { 1966/7-1979/82 }\end{array}$} & J17: 1966/7-1974/5 & \multirow[t]{2}{*}{2} \\
\hline & & J18: 1974/5-1979/82 & \\
\hline \multirow[t]{3}{*}{$V$} & \multirow{3}{*}{$\begin{array}{l}\text { A(upswing): } \\
\text { 1979/82-2008/10 }\end{array}$} & J19: 1979/82-1990/3 & \multirow[t]{3}{*}{3} \\
\hline & & J20: 1990/3-2001/2 & \\
\hline & & $\mathrm{J} 21: 2001 / 2-2008 / 10$ & \\
\hline
\end{tabular}

\footnotetext{
${ }^{30}$ However, it is possible to single out in this phase three shorter (rather than two longer) J-cycles: 1947-1954; 1954-1961 (whose course was somehow interrupted by the 1957 crisis); 1962-1967. The general length of the phase -20 years - allows to speak about three short J-cycles. Such a vague cyclical dynamics was produced by an active Keynesian interference in the cycles, as well as by the difference in the course of the cycles in Europe and the USA (for more details see Grinin and Korotayev 2010b).
} 


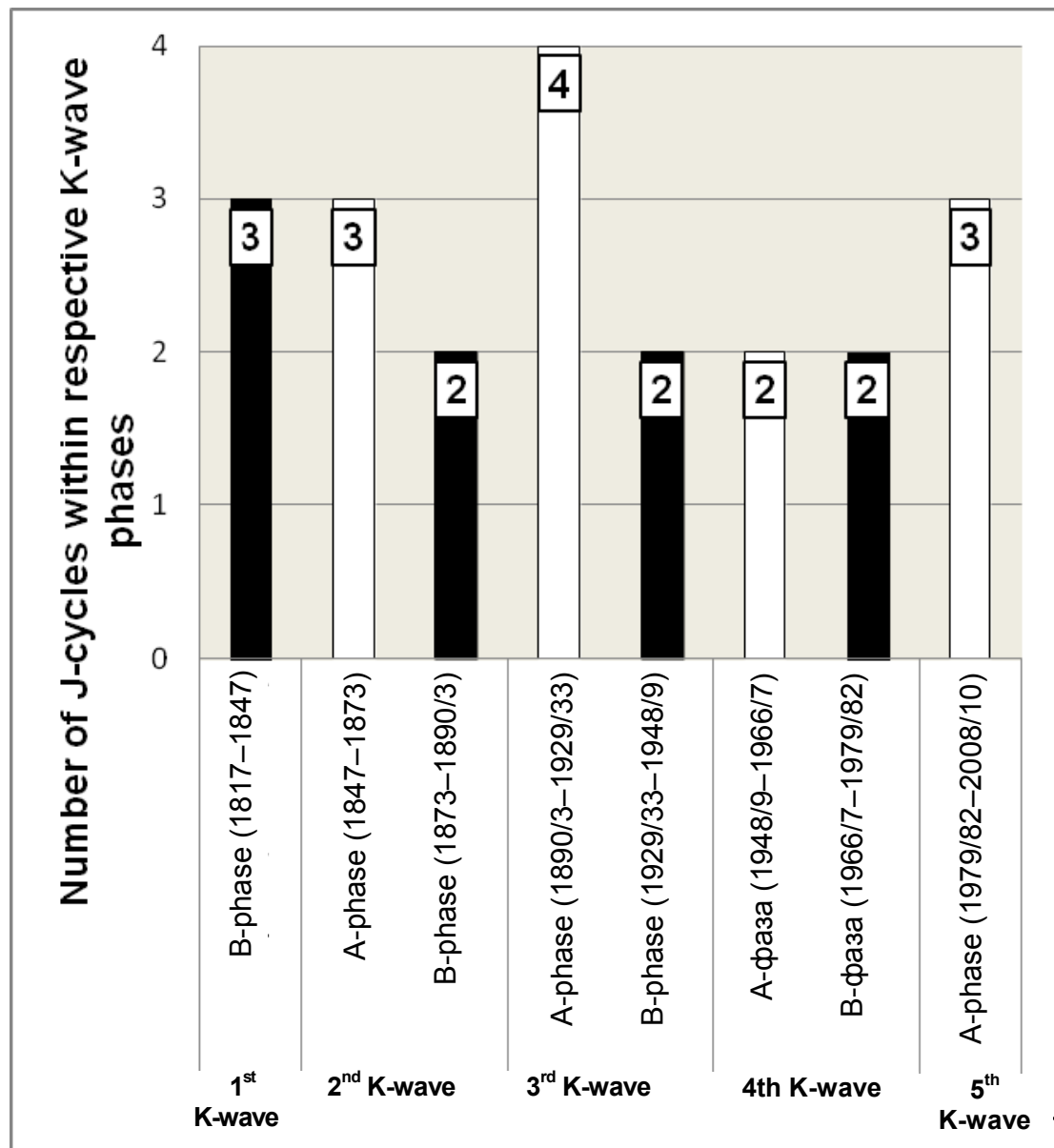

Fig. 3. Correlation between Juglar cycles and Kondratieff waves (the first version) 


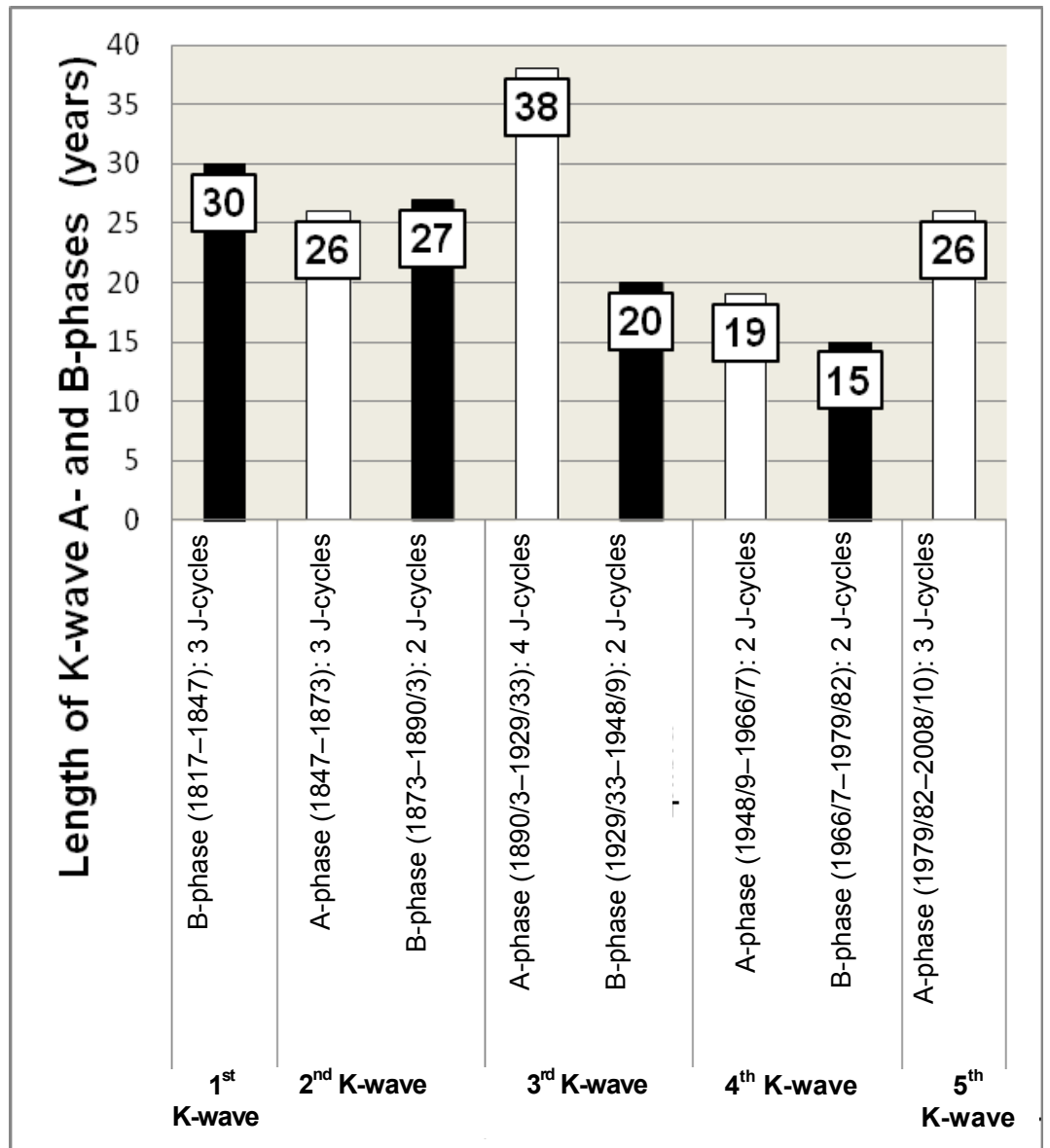

Fig. 4. Length of $\mathrm{K}$-wave $\mathrm{A}$ - and $\mathrm{B}$-phases (the first version)

At this point it appears reasonable to return to the consideration of the general dynamics of the annual world GDP growth rates in 1945-2007 (see Fig. 5): 


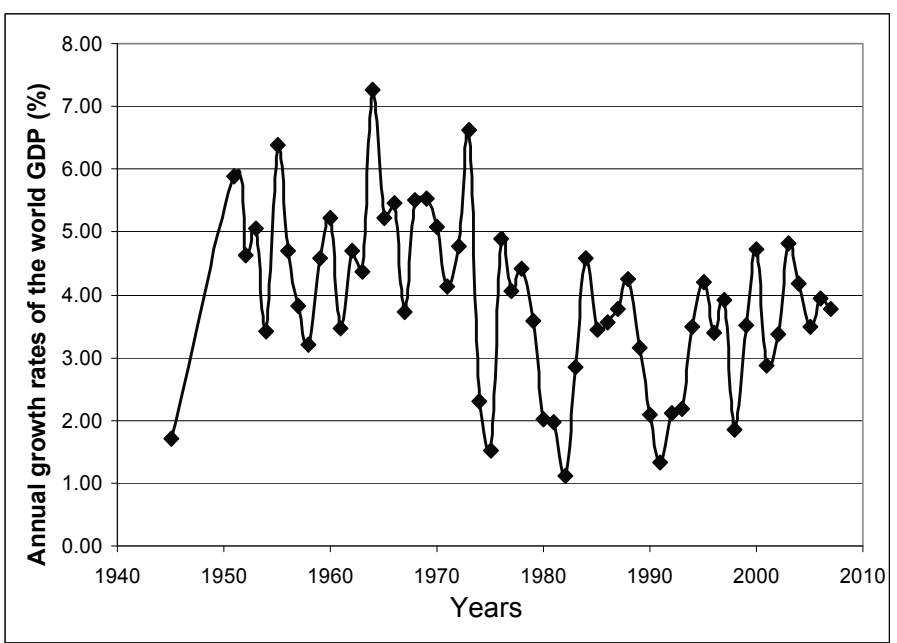

Fig. 5. Dynamics of the annual world GDP growth rates (\%), 1945-2007 Sources: World Bank 2014; Maddison 2010.

This diagram indicates rather clearly an ambiguous position of the $19^{\text {th }} \mathrm{J}$-cycle (1979/1982-1990/3). Following a number of K-wave scholars, we included the $19^{\text {th }} \mathrm{J}$-cycle above into the $5^{\text {th }} \mathrm{K}$-wave A-phase. However, due to the patently transitional character of this cycle, we do not see sufficient grounds to exclude the possibility of its inclusion into the K-wave B-phase. In addition, the diagram suggests that the $1967-1974$ period (the $18^{\text {th }} \mathrm{J}$-cycle) can be considered to be a part of both A-phase and B-phase of the $4^{\text {th }} \mathrm{K}$-wave. In this case, we get a different picture of the correlation between K-waves and J-cycles (see Table 2 and Figs. 6-7). 
Table 2. Correlation between Juglar cycles and Kondratieff waves (the second version)

\begin{tabular}{|c|c|c|c|}
\hline $\begin{array}{c}\text { Serial } \\
\text { numbers } \\
\text { of } K- \\
\text { waves }\end{array}$ & $\begin{array}{c}\text { Long waves' phases and } \\
\text { their dates }\end{array}$ & $\begin{array}{l}\text { Serial numbers and } \\
\text { dates of J-cycles }\end{array}$ & $\begin{array}{l}\text { Number of J- } \\
\text { cycles per the } \\
\text { respective K- } \\
\text { wave phase }\end{array}$ \\
\hline \multirow{3}{*}{$I$} & \multirow{3}{*}{$\begin{array}{l}\text { B (downswing): } \\
1817-1847\end{array}$} & J1: $1817-1825$ & \multirow{3}{*}{ 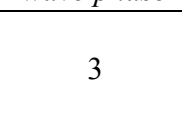 } \\
\hline & & J2: $1825-1836 / 7$ & \\
\hline & & J3: $1836 / 7-1847$ & \\
\hline \multirow{5}{*}{$I I$} & \multirow{3}{*}{$\begin{array}{l}\text { A (upswing): } \\
1847-1873\end{array}$} & J4: $1847-1857$ & \multirow{3}{*}{3} \\
\hline & & J5: $1857-1866$ & \\
\hline & & J6: $1866-1873$ & \\
\hline & \multirow{2}{*}{$\begin{array}{l}\text { B (downswing): } \\
\text { 1873-1890/3 }\end{array}$} & J7: 1873-1882 & \multirow{2}{*}{2} \\
\hline & & J8: $1882-1890 / 3$ & \\
\hline \multirow{6}{*}{ III } & \multirow{4}{*}{$\begin{array}{l}\text { A(upswing): } \\
\text { 1890-1929/33 }\end{array}$} & J9: $1890 / 3-1900 / 3$ & \multirow{4}{*}{4} \\
\hline & & J10: 1900/3-1907 & \\
\hline & & J11: 1907-1920 & \\
\hline & & J12: 1920-1929/33 & \\
\hline & \multirow{2}{*}{$\begin{array}{l}\text { B(downswing): } \\
\text { 1929/33-1948/9 }\end{array}$} & J13: 1929/33-1937/8 & \multirow{2}{*}{2} \\
\hline & & J14: $1937 / 8-1948 / 9$ & \\
\hline \multirow{5}{*}{$I V$} & \multirow{3}{*}{$\begin{array}{l}\text { A(upswing): } \\
1948 / 9-1966 / 7\end{array}$} & J15: 1948/9-1957/8 & \multirow{3}{*}{$3\left(\right.$ or $\left.4^{31}\right)$} \\
\hline & & J16: 1957/8-1966/7 & \\
\hline & & J17: 1966/7-1974/5 & \\
\hline & \multirow{2}{*}{$\begin{array}{l}\text { B(downswing): } \\
\text { 1974/5-1990/3 }\end{array}$} & J18: 1974/5-1979/82 & \multirow{2}{*}{2} \\
\hline & & J19: 1979/82-1990/3 & \\
\hline \multirow{2}{*}{$V$} & \multirow{2}{*}{$\begin{array}{l}\text { A(upswing): } \\
\text { 1990/3-2008/10 }\end{array}$} & J20: 1990/3-2001/2 & \multirow{2}{*}{2} \\
\hline & & J21: 2001/2-2008/10 & \\
\hline
\end{tabular}

\footnotetext{
${ }^{31}$ See the note to the first version of this table.
} 


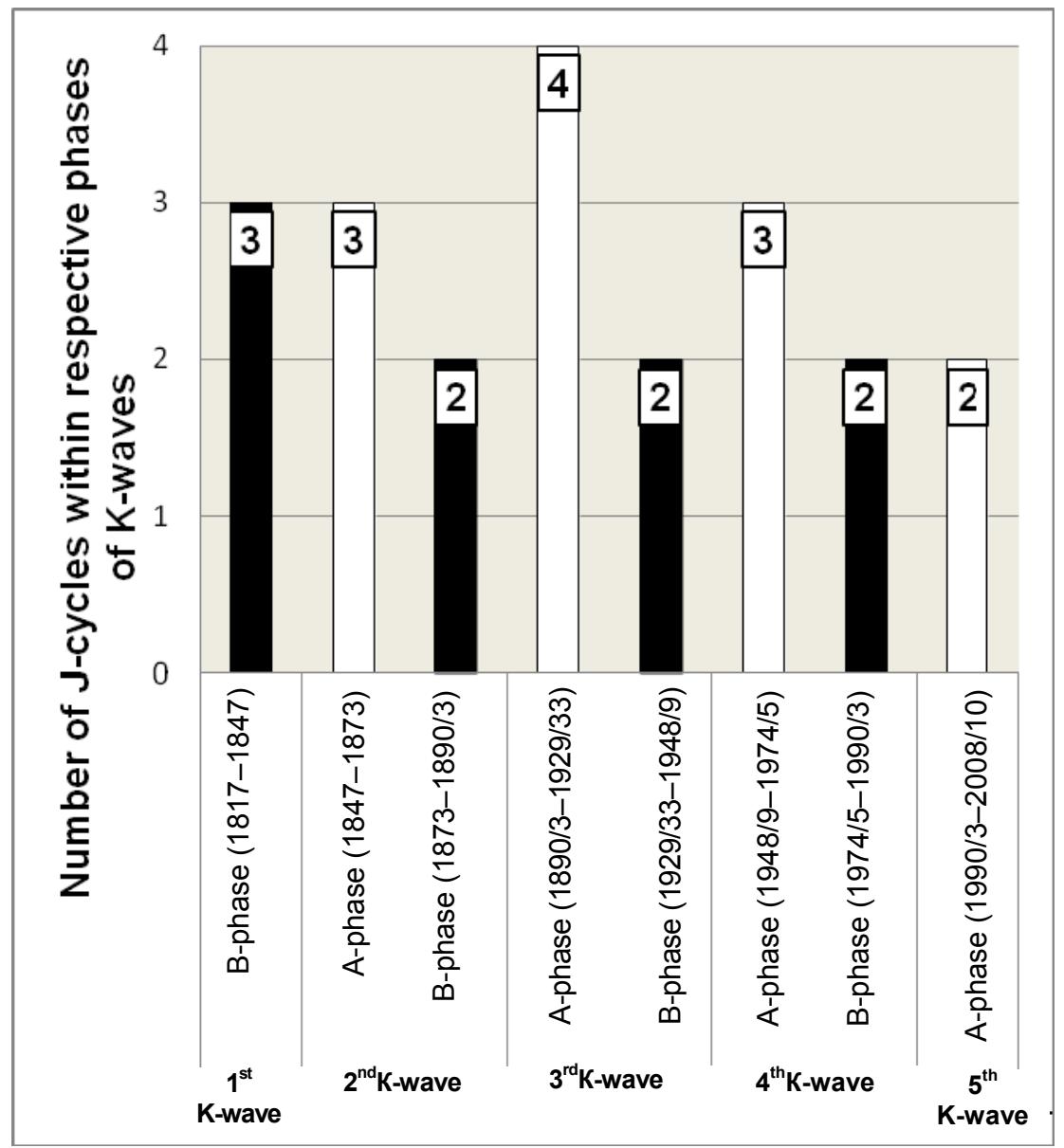

Fig. 6. Correlation between Juglar cycles and Kondratieff waves (the second version) 


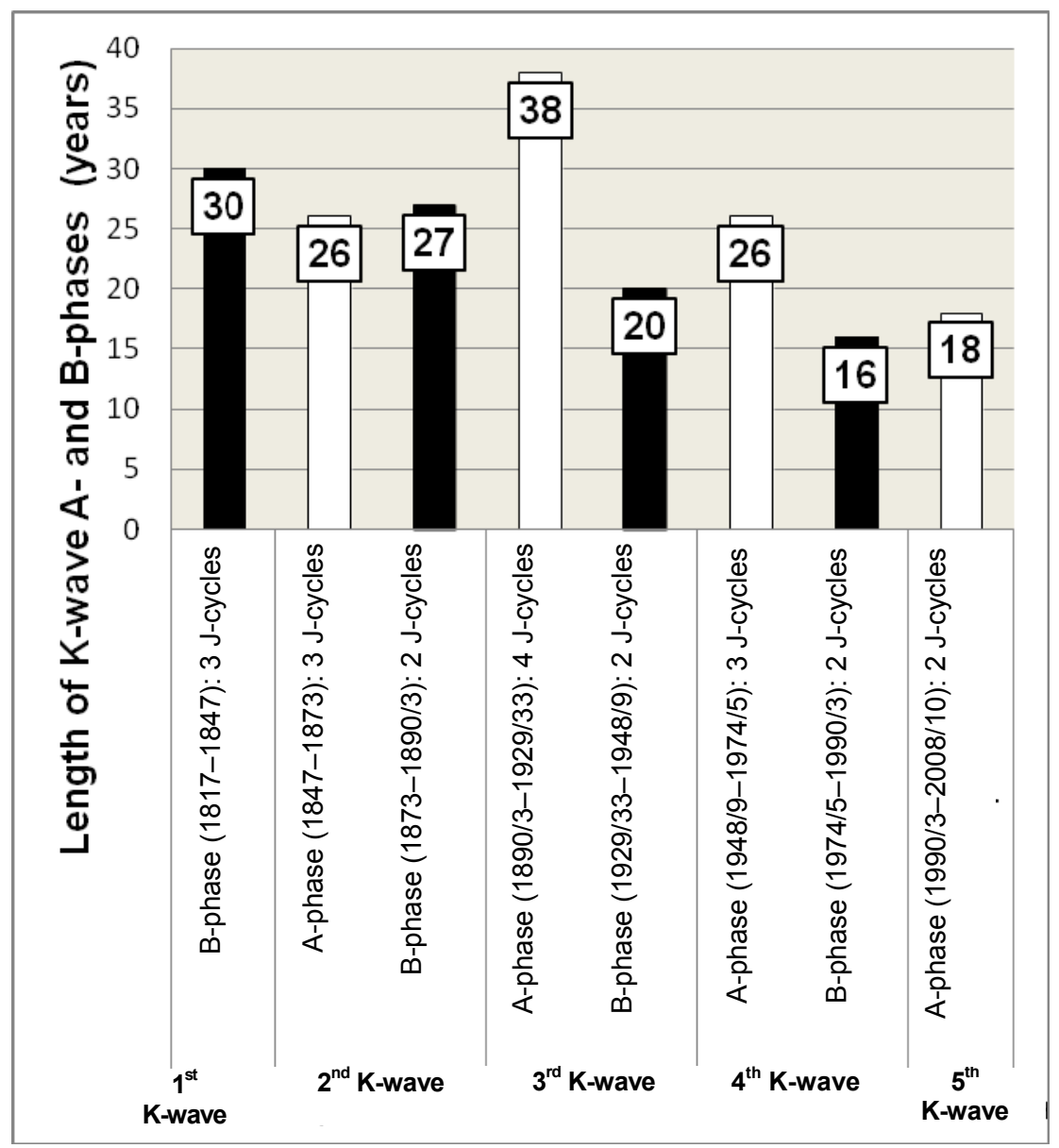

Fig. 7. Length of $\mathrm{A}$ - and $\mathrm{B}$-phases of $\mathrm{K}$-cycles (second version)

We believe that our analysis allows us to make the following preliminary conclusions.

1) First of all, we see that the actual lengths of K-waves, as well as their A- and B-phases do not correspond fully to the 'stylized facts'; in addition, there are significant variations both in the absolute lengths, and the number of J-cycles that fit into them. In the framework of the first version the same number of J-cycles in the A-phase and B-phase within a K-wave is observed in only one case out of three, and in two cases the number of J-cycles in the A-phase exceeds the number of J-cycles in the B-phase. Within the second version the number of A-phase J-cycles exceeds the number of B-phase cycles in all 
the three cases. At the same time, taking into account what has been said in the note to Table 1 the number of A-phase J-cycles may exceed the number of Bphase cycles in all three cases in the first version too. Based on these conclusions, we graphically represent two versions of the relationship between the Jcycles and K-waves in Figs. 10 and 11 at the end of this article: one with equal numbers of J-cycles in the A- and B-phases (Fig. 10), whereas in Fig. 11 this number is unequal (three A-phase J-cycles versus two B-phase J-cycles).

2) Note that we observe in both cases the tendency that we have already discussed above, namely the tendency toward the reduction of the absolute duration of B-phases. In this article we suggest a possible explanation for this phenomenon. With respect to the A-phase this reduction does not appear to be observed in a comparably clear way (and we will suggest our explanation for this phenomenon too). Thus, as we shall see below, due to deliberate action of economic actors upon the Juglar dynamics the duration of A-phase tends to be longer than the one of the B-cycles (irrespective of how we count this duration - in years, or in Juglars).

In general, for both versions of the four A-phases we find $12 \mathrm{~J}$-cycles, whereas for four B-phases we find only 9 J-cycles.

3) Much has been written about the absolute duration of K-waves measured in years (see above), so we will not dwell on this issue here. But if we use 'Juglar' as a unit of measurement of the length of K-waves, we must note that this length fluctuates between 4 and 6 'Juglars'. On average, if 21 'Juglars' are divided into four waves (three full waves and two 'halves'), then one has on average 5.25 'Juglars' per one K-wave (note that with the second version of the estimate of the duration of the $4^{\text {th }} \mathrm{K}$-wave A-phase, we will get on average 5.5 'Juglars' per one K-wave).

However - and this is crucial for the theory presented in this article whatever the duration of the phases, we see in any case an integral number of J-cycles in any K-wave. This shows that the deep and tangible connection between J-cycles and K-waves is observed on the 'essential' rather than phenomenological level.

4) Thus, the idea of measuring the duration of the K-phase waves not only in years, but also in 'Juglars' has a very specific meaning, as the number of 'Juglars' in different waves and phases respectively ranges from 4 to 6 and from 2 to 4 (see, e.g., Figs. 6 and 7 above). In this case, the 'economic time begins to be measured not in years, but in cycles' (Avramov 1992: 64).

Thus, depending on the chosen periodization, the number of 'Juglars' in the same K-wave and the same phase of the wave varies. For example, according to Version 1, the fourth K-wave includes 4 'Juglars'; according to Version 2 it consists of 5 'Juglars'. Accordingly, the A-phase of the $5^{\text {th }} \mathrm{K}$-wave includes either three or two 'Juglars'. And the latter is very essential for the development of economic forecasts, as we shall see below. 
When you add an electron to an atom (or take an electron from it), this atom undergoes a substantial change (it becomes a positively or negatively charged ion instead of the neutral atom). In a similar way, the extension/contraction of A- or B-phases by one Juglar leads to the significant changes in the economy and economic moods, the tone of economic theories, as well as to the intensification in search of anti-crisis measures.

5) Kondratieff's conclusion that 'during the rise of the long waves, years of prosperity are more numerous, whereas years of depression predominate during the downswing' (1935: 111) may be augmented with the conclusion that, generally, at the K-wave B-phases J-cycles are longer than at the A-phases. In particular, the calculation shows that at the A-phase the average duration of one J-cycle is about 9-9,1 years (and if we add an additional cycle to the A-phase of the $4^{\text {th }} \mathrm{K}$-wave, this duration will be equal to about 8.3 years), while the average duration of one $\mathrm{J}$-cycle at the B-phase is about $10,2-10,3$ years. We attribute this to the following circumstances: a) within B-cluster J-cycles we observe the lengthening of phases of recession and depression in comparison with A-clusters, and b) in the A-cluster J-cycles one observes so powerful phases of expansions, that sub-phases of overheating, acute crisis and recession phase occur very fast, within a rather short period of time.

6) The forecast may change substantially depending on what version of the periodization of the $5^{\text {th }} \mathrm{K}$-wave will be chosen. For example, in Chapter 2 of our previous monograph (Grinin, Korotayev, and Tsirel 2011) we offered two versions of forecasting the dynamics for the forthcoming two decades. Note that in both cases we base ourselves on the assumption that the A-phase of the $5^{\text {th }}$ $\mathrm{K}$-wave must be longer that its B-phase. In any case, the A-phase of the $5^{\text {th }} \mathrm{K}$ wave corresponds to three J-cycles, whereas its B-phase is most likely to consist of two 'Juglars'.

We find the first version to be more probable; it suggests that the A-phase of the $5^{\text {th }} \mathrm{K}$-wave ended with the start of the global crisis in 2008, when the B-phase started. In this case - taking into account the active search throughout the World System for effective anti-crisis measures - the duration of the B-phase should not be more than two 'Juglars', and it is very likely that the duration of J-cycles within the cluster should not be very long. We should also take into account the tendency for the duration of B-phases to decrease. But at the same time B-phase shall not be less than two 'Juglars', whereas, as we have seen, short J-cycles are less typical for B-phases than for A-phases. Therefore, we can suggest a tentative forecast that the present B-phase of the $5^{\text {th }} \mathrm{K}$-wave will have a duration of 14 to 18 years.

7) The presence of more than one version of periodization and forecasts should not be of any surprise - taking into account the extreme narrowness of the empirical basis. Indeed, one can talk reliably about Juglar cycles only starting from the first clear Juglar cycle of 1817-1825. Therefore, to date, we can 
only talk about three full K-waves and two 'halves', in which the interaction between Juglar and Kondratieff dynamics has been clearly observed, which does not meet the minimum requirements for regular analysis of cyclic processes (Avramov 1992: 72; Grinin and Korotayev 2013). In his paper published in 1992, Avramov maintained that within the relative chronology of the theories of his day, the stage of development of the long-wave theory could be compared with the situation in the medium-term cycles theory in the 1870s (Ibid.). With the passage of time, the theory of K-waves approached a level of development of the theory of medium-term cycles at the time of the first edition of Tugan-Baranovsky's classical volume in 1894; however, Tugan-Baranovsky himself then said about the theory of medium-term cycles that it was 'the least studied subject in the economic literature' (Tugan-Baranovsky 1894: 377).

\section{Verbal Model of K-Waves}

\section{General Outline}

The main 'intrigue' of the K-wave phenomenon is a relatively regular period of the change from $\mathrm{K}$-wave upswings to $\mathrm{K}$-wave downswings, and vice versa. Our general ideas that allow to understand better the mechanism of changing trends, can be presented as follows:

1) Both trends (upward and downward) are present in the modern economy at the same time and always (so periods when there is no qualitative or quantitative development at all, are extremely rare, just one hardly find cases of overall growth without any stagnant sectors at all); but at every phase one or those trends predominates.

2) The change of the trend is largely prepared by its exhaustion, i.e. the weakening of one trend paves the way for the strengthening of the other.

3) In other words, one can observe an evident negative feedback between the trends, which strengthens with each new medium-term cycle (until the trend does not change), since the nature and results of each J-cycle is a signal for a particular type of action of active participants in the process (from individual entrepreneurs to whole states and supranational organizations). Rising prices and profit margins, as well as high demand cumulatively lead to the expansion of production. The falling rate of profit, reduction of the growth rates, etc. lead to the reduction in investment and the search for new innovative solutions.

4) The nature of the trend depends largely on the type of action chosen by the majority of participants in the process.

5) The relatively regular characteristic period of the K-wave phase alteration is determined by the relative stable characteristic period of the J-cycles (711 years), whereas J-cycle clusters (that mostly include three J-cycles each) tend to last somewhere in the range between 20 and 30 years. We would also add that, in relation to the theory of generations, 10 years is not a period that is long enough to significantly alter the generation of businessmen (and especially 
politicians) so that to more proactive and less cautious entrepreneurs could appear. Two or three J-cycles (7-11 years each) are just sufficient to renew the generation of businessmen.

6) The only exception is constituted by the upswing (A-) phase of the First $\mathrm{K}$-wave (the late $1780 \mathrm{~s}$ - the early $1790 \mathrm{~s}-1810-1817$ ), as it was generated mostly by external [military] factors (see for more details below). However, the B-phase of the First K-wave started with the first J-cycle (approximately 1815/1818-1825) that ended the first large-scale cyclical crisis in 1825.

Thus, the alteration of upswings and downswings is inherent in the properties of the industrial and post-industrial economy that seeks to expand, but is impeded by all sorts of obstacles, and the rather regular duration of K-wave upswing and downswing phases is connected with the time frames of the J-cycle length.

\section{Notes on Dynamics}

As we have already mentioned above, in the modern economic systems the periods of predominantly qualitative (innovative) development are followed by periods of mainly quantitative development and vice versa. However, it is important to note that such a development occurs with sufficient frequency not within a single country, but only in the framework of the World System as a whole (but in some periods, it can also be observed in the core states of the World System). In addition, each of these pulsations is associated with the expansion of the World System and the change of its configuration. This leads to a change in the economic and political relations within the boundaries of the World System. The mechanism of a rather fast impulse propagation in the framework of the World System and relatively synchronous change of development vectors are associated with the increasingly close interaction of economies and societies through a variety of financial and other links.

Secondly, by itself the alteration of innovation and modernization trends may not have sufficiently clear time limits. Modernization trends within the World System cannot arise from the investments and implementation of major innovations in different countries because the timing and modalities of these processes are very different, and investments themselves cannot be synchronized. To repeat: the timing and the relative accuracy of the K-wave phase alteration are determined by the nature of the J-cycle clusters. During the $\mathrm{K}$-wave upswing one can observe a rapid expansion, which inevitably requires significant changes from society. ${ }^{32}$ However, such changes are far behind in time from the objective need in them (due to the time required for the emergence of awareness of the problem, its discussion, the search and decision-making, implementation of solutions in practice, etc.). Such a delay is one of the important reasons why we can frequently observe a period of more difficult ('downswing')

\footnotetext{
${ }^{32}$ This was noticed already by Simon Kuznets (1966).
} 
development (B-cluster of J-cycles) after the upward phase.) During the struggle with the crisis-depressive phenomena economic actors are searching for ways to overcome difficulties. As a result, in some societies a social innovation emerges, which then begins to be applied not only in this society but also in many others. Then new upward momentum in some societies creates conditions for transition to a new A-phase upswing. But the wide (i.e. in many societies) awareness of the benefits of such a social innovation does not happen immediately, but around the second J-cycle of a new A-phase.

The emergence of a variety of technical and social innovations and their successful testing lead to a new round of extensive World System growth. This is a very important fact, which attracts little attention, but it is the expansion of modernization that enhances the momentum of the A-phase. Expansion of modernization (combined with technological and social innovations) leads to the expansion and reconfiguration of the World System, which creates the need for a change in relations within the World System. Results of the extended modernization become visible in 10-15 years. By this time, prices can reach very high scores; many large 'bubbles' emerge in the economy under the influence of excessive demand for resources. However, the momentum of modernization loses its original strength. In a situation of prolonged overheating of the economy, such a slowdown leads to various kinds of difficulties and increased global competition, the burst of bubbles, and Juglar crises. Finally, we see the transition to a B-cluster of J-cycles (and to a B-phase of the following K-wave).

We also note that one can observe as a result of the development of each J-cycle cluster the change of the businessmen generations, their approach to doing business, the attitude to the different parameters, etc. Thus, again, the idea of generational change influence on the alteration of K-wave phases may also find its place in the synthetic theory of the K-waves.

Main Principles for the Development of the $K$-Wave Model

So, to summarize. The alteration of the K-wave upswings and downswings is determined by the following points:

a) Both trends (upward and downward) are always present, which, incidentally, can be clearly seen in the continuous alternation of J-cycle phases of rise and recession;

b) periodically some trend is amplified at the expense of another at the level of both medium length cycles and long waves;

c) the development of every trend is initially enhanced by some sort of positive feedback;

g) but the strengthening of this trend eventually leads to its weakening and the strengthening of the countertrend; 
d) in other words, the phase change mechanism is defined by the switching time of negative feedback, which leads to the increase in strength of the countertrend;

e) thus, there is a time lag that is essential for the generating of cyclical dynamics;

g) the nature of the medium-term cycles and their phases are the most important signals to business and society, defining the model of their strategy;

h) more active (in the B-phase) or less active (during the A-phase) innovative-reforming activities are the most important factor affecting the occurrence of negative feedback, and the latter ultimately leads to a change in the phase of $\mathrm{K}$-waves.

\section{Phase Alteration in the $K$-Wave Model}

When the A-phase (upward trend) begins, this puts into action the positive feedback effect in the form of investment, growth in demand (reinforcing the rise in prices and GDP) and other activity that warms up the economy. This positive relationship operates at the level of individual companies and intersocietal contacts (trade, financial flows, etc.). Furthermore one observes a new level of positive feedback - the World System - due to the fact that in the World System the modernization process accelerates as a whole under the influence of growth and success thanks to the emergence at the B-phase of a system of technical, financial and social innovations. This leads to a temporary acceleration of positive feedback and delay the appearance of negative feedback. This lag (taking into account the point that the World System modernization is a fairly lengthy process) can be about 10-20 years. But when modernization is on the wane the negative feedback mechanisms start being felt as a reaction to excessive overheating of the preceding period: reducing demand, falling prices, falling profit margins, decrease of investment activity, etc. As a result, the downward trend begins to dominate, and a new B-phase starts.

With the start of a B-phase a certain positive feedback mechanism starts working, as over some time one can observe the strengthening of the process by which within the World System more and more economic agents and even whole countries begin to experience difficulties and to change their strategies (to reduce investments, to reduce costs, not to pay debts, etc.). In other words there is a natural chain reaction of negative momentum transfer through the World System. Further, this positive feedback is strengthened and stretched in time due to the fact that the necessary changes in the societies were not made in due time (in phase A), and most importantly - due to the fact that the emergence and launch of necessary social (and other) innovations require quite a long time.

This lag is also estimated to be about 10-20 years (taking into account the need to change policy, to enact laws, etc.). One should keep in mind periodically occurring temporary improvements (in expansion phases of J-cycles) that, 
paradoxically, hinder the process of change in society. Finally, after the introduction of such social innovations (which generally add up to the overall system with other types of innovation: technical, financial, etc.), and after they begin to show its effectiveness, a negative feedback starts to be felt, which leads to a decrease in negative trends and strengthening of the upward trend. And as these phenomena emerge at least within one or a few societies of the World System, the upward momentum of them gets distributed throughout the whole world. A new A-phase begins, which accelerates the positive feedback due to the introduction of sets of innovations, which again leads to an extension of the World System or growth of its complexity.

This system of relationships is graphically represented at the end of this article in Figs. 10 and 11.

\section{Relationships Between K-Waves and J-Cycles}

$K$-Waves and J-Cycle clusters

J-cycle clusterization. As has already been mentioned, the most mysterious moment in K-waves is their relatively stable duration (as well as the relatively stable duration of their phases - respectively, 40-60 years and 20-30 years). None of the theories has been able to explain this phenomenon satisfactorily; none of them has been able to clearly separate economic or social factors that would clarify the reasons behind such rhythm. In our opinion, the only real factor that can set the pace of certain duration of Kondratieff waves and their phases are Juglar cycles. We would like to underline again that the J-cycles appear in the ontological sense more real than K-waves, hence these are J-cycles that should be considered as basic structural units, creating in the totality of their processes K-waves and their phases (and not vice versa).

In the analysis of such a relationship between J-cycles and K-waves it is necessary to take into account the point that in addition to general model properties of J-cycles one can identify more common properties for groups of nearby J-cycles. These properties are derived not only from their greatest historical proximity, but also from the fact that they have a general trend, as well as from the fact that the nature of their crisis-depressive phases and phases of growth and prosperity has certain properties in common.

Thus, J-cycles can be seen not just as structural units of the same type, but as a more complex system that represents a single chain/cluster of two, three or more J-cycles possessing within the cluster additional common features.

It appears necessary to emphasize that: a) such clusters of J-cycles tend to have a duration of roughly 20-30 years (assuming that the cycle is 7-11 years, then three cycles in duration constitute 21-33 years), which correspond to average lengths of K-wave phases; b) an organic link between the J-cycles and $\mathrm{K}$-waves is particularly supported by the fact that the phase boundaries of Kondratieff waves (as well as boundaries of particular waves themselves) in many 
theories practically coincide with the boundaries of certain medium-term cycles and crises. $^{33}$

The character of J-cycle clusters correlates with the character of K-wave phases. Of course, this cannot be accidental; actually, this is rather accounted for by certain mechanisms of reaction of particular societies and the World System to J-cycles. ${ }^{34}$ Incidentally, it appears necessary to note that the ratio between the extreme values of duration periods of K-waves (40-60 years) and J-cycles (7-11) is very similar: $7: 11 \sim=0.64 \sim 40: 60=0.66$.

On the Correlation between J-Cycles and K-Wave Phases

As was already established by Kondratieff, within upswing phases of K-waves J-cycles are characterized by stronger expansions and weaker depressions, whereas within K-wave downswings a contrary pattern is observed.

Nikolay Kondratieff himself addressed the analysis by Arthur Spiethoff (Kondratieff 2002: 380). Below is Spiethoff's table (Table 3). The other researchers' analysis proves Kondratieff's assertions concerning the proportions between the number of contraction and growth years at different phases of Kwaves. In particular, William Mitchell $(1913)^{35}$ concluded that within the longterm inflationary trends (i.e., at the A-phase of the K-wave), the phases of growth and depressive phases in Juglar cycles with respect to the USA are in the ratio $2.7: 1$, and in the periods of prolonged deflation (i.e., at the B-phase of the $\mathrm{K}$-wave) the ratio is only $0.85: 1$. Alvin Hansen, who used to be rather sceptical of the K-waves theories, nevertheless, found that for the period from 1872 to 1920 (i.e., second - third K-wave) during the upward rise in prices (at the A-phase), an average duration of depression was two years, and at the downtrend (the B-phase) it was 5.3 years. And conversely, the respective rises at the A-phase were by 1.8 times longer than at the B-phase (Hansen 1951). We interpreted these calculations in the Table 3.

\footnotetext{
${ }^{33}$ Initially long waves were considered as combinations of a few adjacent medium-term business cycles (Burns and Mitchell 1946; van der Zwan 1980; Delbeke 1987; van Duijn 1983). These were still regarded as a sort of rather mechanical combination, whereas the idea that adjacent Jcycles could form a real system was expressed very rarely and was not developed in any significant way.

${ }^{34}$ Some researchers speak about a tight connection between Kuznets cycles and K-waves (see, e.g., Rumyantseva 2003; Akaev, Rumyantseva et al. 2011). We do not exclude the possibility that such a connection does exist. However, Kuznets swings have been detected mostly in the USA (see Kuznets 1958; Abramovitz 1961: 230; Hansen 1951; see also Akaev, Rumyantseva et al. 2011: 91), whereas the J-cycles may be traced in all the main countries of the World System. In addition, Kuznets cycles are much less pronounced and do not have so dramatic crisis phase; that is why there is some sense in the prevalent tendency to denote them as 'swings', rather than as 'cycles'.

${ }^{35}$ See also: Burns and Mitchell 1946: 438.
} 
Table 3. The correlation between the years of upswing and depression at the A- and B-phases according to Spiethoff

\begin{tabular}{|l|c|c|}
\hline \multicolumn{1}{|c|}{ Periods } & Upswing years & Depressive years \\
\hline $\begin{array}{l}\text { The downswing of the long cycle } \\
\text { from } 1822 \text { to } 1843\end{array}$ & 9 & 12 \\
\hline $\begin{array}{l}\text { The upswing of the long cycle from } \\
1843 \text { to } 1874\end{array}$ & 21 & 10 \\
\hline $\begin{array}{l}\text { The downswing of the long cycle } \\
\text { from } 1874 \text { to } 1895\end{array}$ & 6 & 15 \\
\hline $\begin{array}{l}\text { The upswing of the long cycle from } \\
1895 \text { to } 1912\end{array}$ & 15 & 4 \\
\hline
\end{tabular}

Table 4. The correlation between the duration of upswing and depression phases according to some economists

\begin{tabular}{|l|c|c|}
\hline \multicolumn{1}{|c|}{ Economist } & A-phase & B-phase \\
\hline A. Spiethoff & $2.5: 1$ & $0.6: 1$ \\
\hline W. Mitchell & $2.7: 1$ & $0.85: 1$ \\
\hline A. Hansen & $3: 1$ & $0.75: 1$ \\
\hline
\end{tabular}

Modern data on characteristics of upswings and recessions for 1919-1994 period confirm the presence of this regularity - the lengthening of expansion phases during $\mathrm{K}$-wave upswings and the lengthening of recession phases during K-wave downswings (for details see Rumyantseva 2003: 25).

Thus, we can speak of two types of chain-clusters of J-cycles characterized by specific boom-depression patterns: 1) at upswing phases of $\mathrm{K}$-waves J-cycle depressions are less pronounced, and J-cycle expansions are more durable; 2) at downswing phases of K-waves J-cycle depressions are more pronounced, and J-cycle expansions are less intense and prolonged. Accordingly, the first type of J-cycle chain-clusters can be called 'A-clusters', whereas the second type can be denoted as 'B-clusters'.

As has already been mentioned, the relationship between $\mathrm{K}$-waves and J-cycles has not been studied quite sufficiently. Recall that Kondratieff pointed out that J-cycles are a sort of interwoven within $\mathrm{K}$-waves and depend on the latter. In particular, he wrote, 'The long waves belong really to the same complex dynamic process in which the intermediate cycles [i.e., J-cycles. L. G., $A$. K.] of the capitalistic economy with their principal phases of upswing and depression run their course. These intermediate cycles, however, secure a certain stamp from the very existence of the long waves. Our investigation demonstrates that during the rise of the long waves, years of prosperity are more nu- 
merous, whereas years of depression predominate during the downswing' (Kondratieff 1935: 111).

However, it seems that the relationship between $\mathrm{K}$-waves and J-cycles is not only significantly deeper and more complex, but - most importantly -the causal relationship between them in general looks different. Hence, Kondratieff was not quite correct when he contended that the nature of $\mathbf{J}$ cycles depended on the nature of the respective K-wave phases; the actual situation seems to be simply the opposite - this is the nature of the respective J-cycle clusters that largely determines the nature of the respective $\mathrm{K}$ wave phases.

This view on the causal relationship between the two types of cycles emerges from the fact that Juglar cycles are more observable empirically than K-waves, which, in the words of Maevsky (1992: 58), 'appear as a kind of surreal force that cannot be perceived directly'. The factors that produce J-cycles are also clearer and better described. Moreover, the presence of these factors has been confirmed 'experimentally', because more than half a century of economic regulation in many countries has proved that the course of Juglar cycles can be influenced by certain measures of economic policy that this course can be modified, and in some cases the critical phase of those cycles can be even avoided. In the meantime any successful attempts to influence consciously the course of Kondratieff waves do not appear to be known. ${ }^{36}$

\section{General Causes and Mechanisms of Economic Cycles}

$\mathrm{J}$-cycles and K-waves arise from the general properties of the industrial economy - the ability of expanded reproduction (on this feature see, e.g., Kuznets 1966; Gellner 1983; Abramovitz 1961; Poletaev and Saveljeva 1993; Grinin 2003, 2006a, 2007a, 2007b, 2009b; Grinin and Korotayev 2012). Economic growth cannot go on constantly and continuously; therefore, slowdowns are inevitable; and those slowdowns can only be overcome through qualitative changes. Thus, the constant expansion and development imply that the structure within whose framework this development takes place, sometime should be substantially modified. Especially such changes should occur as a result of technological revolutions (see, e.g., Perez 2002, 2010, 2011, 2012; Grinin $2003,2009 b)$. But, as a rule, such a change lags behind the more dynamic economic (technological) component underlying the expanded economic growth. Therefore, this change occurs in the form of more or less severe crises that, in fact, generate cyclical fluctuations.

\footnotetext{
${ }^{36}$ Note that reality of medium-term cycles is recognized by many (though still not all) economists that is expressed in the fact that in most textbooks on macroeconomics these cycles are discussed in special chapters or sections (see, e.g., Mankiw 1994: Ch. 14; Sacks and Larren 1996: Ch. 17; Abel and Bernanke 2008a: Ch. 8), whereas reality of long Kondratieff cycles recognized minority of economists (and - consequently - references to them in Economics textbooks are either absent or very scarce).
} 
There are certain important (and not random) similarities between J-cycles and K-waves in terms of their 'structure' as regards some cyclical factors and certain properties of cyclical processes. The understanding of those similarities must be able to further clarify the mechanisms of interaction between those different cycles. There are also important similarities both in terms of the nature and mechanisms of transmission of impulses (leading to the generation of J-cycles and K-waves) from one country to another within the framework of the World System. Both cycles never occur only within a particular society, they always extend beyond individual societies and are somehow connected with the world-system processes. This is all the more important that J-cycles (especially J-crises) always tend to become global, or at least taking place simultaneously in a number of societies. Thus, through J-cycle ups and downs within the World System momentum of growth and decline is transmitted very quickly and fairly synchronously. But, of course, for the K-wave dynamics Juglar cycles within the World System leaders are of special importance.

\section{Mechanism of Influence of J-Cycles on the Temporal Rhythm of K-Wave Alteration}

Emergence and Resolution of Societal Structural Crisis within A- and B-Clusters of J-Cycles

How can medium-term cycles affect the dynamics of upward and downward phases of long cycles?

Mechanism of change in phase K-wave, its A-phase with respect to its dependence on J-cycle looks like this (see also the end of this article, Figs 10 and 11). More severe in their manifestations, the crises/depressive phases of $\mathrm{J}$-cycles at a downswing $\mathrm{K}$-wave phase inevitably require from societies deeper and more radical changes, not only in technical and technological aspect, but also in social, legal, political, ideological, and cultural aspects, as well as in the field of international relations and world-system links. Otherwise, a society will not be able to overcome the negative effects of economic crisis and come out of depression.

Only a profound change in many different areas of society, as well as new approaches to the regulation of the economy allow eventually the transition to a significant expansion. ${ }^{37}$ This has already been discussed earlier. The cluster structure of two J-cycles (see Fig. 11) can be schematically represented as follows: the first cycle - awareness of the difficulties and search for counterdepression and reformist measures, the second cycle - the introduction of anticrisis measures and their first results. With three cycles the following pattern can be identified (see Fig. 10): the first cycle - awareness of the difficulties, the

\footnotetext{
${ }^{37}$ Recall that Americans and Europeans had to carry out very deep reforms during and especially after the Great Depression of the late 1920s and 1930s (see Lan 1976; Kindleberger 1973)
} 
second - search for counter-depression and reformist measures and their application, and the third cycle - the time required to develop the result.

Ultimately the struggle with depressions, conducted changes, as well as introduced innovative technologies lead to the replacement of a J-cycle B-cluster with an A-cluster (and, thus, to the transition from a $\mathrm{K}$-wave downswing to a $\mathrm{K}$-wave upswing).

As a result, there is a transition to a new system of relations, which opens the possibility for economies to develop in the coming decades without so strong crisis manifestations ${ }^{38}$ However, since further development proceeds in a relatively soft way, the need for reforming and modernizing relations weakens. Accordingly, the society experiences insufficient changes compared with those that are necessary to re-start rapid growth, whereas any cycle is associated with an increase in structural economic, social, political and other problems. And if they are not resolved, this will lead to the amplification of negative trends, as a result of which rapid economic growth becomes impossible, or there are internal and international problems leading to various crises. Within about three J-cycles potential of free growth is exhausted, and the problems are accumulating. Next there is a powerful crisis, triggering a more or less protracted depression. As a result, an upswing A-cluster of J-cycles is replaced with a downswing B-cluster that corresponds to the $\mathrm{K}$-wave B-phase.

Thus, it is through the medium-term economic cycles in the downward phase of the K-wave conditions are being prepared for the transition to the K-wave upswing. The stronger the crises, the weaker the expansions, and the more intense the structural changes. In turn, less painful crisis-depressive phases of J-cycles at K-wave upswings causes them to turn downswing phases (this is the turn after certain euphoria, and we had an 'honor' to observe such a development in the late 2000s and the early 2010s). That is why the most severe crises are crises at the turning points from the K-wave upswings to the K-wave downswings (in particular, the crisis of 1847, 1873, 1929, 1973, as well as the current global crisis that started in 2008.

So, in the upswing phase, when there is a more intensive growth, cyclical crises resemble a kind of 'stumbling when scooting', when excessive speed leads to inevitable stops and setbacks. However, within A-clusters J-cycles are lesser related to each other; they are rather more similar to isolated events. These are crisis of growth, during which structural problems within societies (and in general within the World System) get accumulated. At the downward phases of the K-wave crises are very different. They are much more closely related to each other, either directly, so that the next crisis is a sort of continuation of the first (e.g., the crisis of 1937 was a sort of continuation of the previ-

\footnotetext{
${ }^{38}$ Menshikov and Klimenko (1989) use the following metaphor - they say that 'society changes its skin' while going through a Kondratieff wave.
} 
ous crisis that started in 1929), or they go against a common negative background (e.g., the cycles of 1875-1895 period went against the background of a protracted agrarian crisis, and the J-cycle crises of 1971-1982 period went against the background of currency, commodity and energy crises). This is explained by the fact that such crises are structural in nature, as they resolve complex structural problems that were accumulated in the previous upswing period. Moreover, military, political or revolutionary crises (as well as world wars) fit rather well in those downward phases, as those crises act as the components of a general world-system crisis that make people change the relationship structure within the World System . In short, these are structural crises that lead to structural changes.

\section{Additional Notes}

An Example of More Active Social Activities during K-Wave B-Phases in Comparison with K-Wave A-Phases

To illustrate the idea that in the economically prosperous periods of a $\mathrm{K}$-wave A-phase societies tend to change less than in the period of crisis in depressive phases, we analyze the average annual number of days of meetings of the U.S. Congress since 1790 to the present. At the same time we have moved the origin period for meetings' calculations for each phase by five years as this can be estimated as average minimum time required for an adequate understanding of the situation (i.e., schedule for Column 4 lag behind the respective schedule for column 3 by five years).

Table 5. Number of days of sessions of the US Congress corresponding to different $\mathrm{K}$-waves and their phases

\begin{tabular}{|c|c|c|c|c|c|}
\hline $\begin{array}{c}\text { K-wave } \\
\text { seria- } \\
\text { number }\end{array}$ & K-wave phase & $\begin{array}{c}\text { K-wave } \\
\text { phase } \\
\text { datings }\end{array}$ & $\begin{array}{c}\text { Corresponding } \\
\text { periods of Congress } \\
\text { sessions }\end{array}$ & $\begin{array}{c}\text { Overall } \\
\text { number } \\
\text { of ses- } \\
\text { sion } \\
\text { days }\end{array}$ & $\begin{array}{c}\text { Average } \\
\text { number } \\
\text { of ses- } \\
\text { sion } \\
\text { days per } \\
\text { year }\end{array}$ \\
\hline 1 & 2 & 3 & 4 & 5 & 6 \\
\hline \multirow{5}{*}{$I$} & A: upswing & $1789-1817$ & $\begin{array}{c}1794-1822 \\
(29 \text { years })\end{array}$ & 4263 & 147 \\
\cline { 2 - 6 } & B: downswing & $1818-1847$ & $\begin{array}{c}1823-1852 \\
(30 \text { years })\end{array}$ & 4931 & 164,4 \\
\hline & A: upswing & $1848-1873$ & $\begin{array}{c}1853-1878 \\
(26 \text { years })\end{array}$ & 4820 & 185,4 \\
\cline { 2 - 6 } & B: downswing & $1874-1893$ & $\begin{array}{c}1879-1898 \\
(20 \text { years })\end{array}$ & 3904 & 195,2 \\
\hline
\end{tabular}

\footnotetext{
${ }^{39}$ The dates in this column do not take into account versions of the starts and ends of various phases mentioned in Table 5.

${ }^{40}$ Taking the five-year lag into account (see above).
} 


\begin{tabular}{|l|l|c|c|c|c|}
\hline 1 & 2 & 3 & 4 & 5 & 6 \\
\hline \multirow{4}{*}{$I I I$} & A: upswing & $1894-1929$ & $\begin{array}{c}1899-1934 \\
(36 \text { years })\end{array}$ & 7242 & 201,2 \\
\cline { 2 - 6 } & B: downswing & $1930-1948$ & $\begin{array}{c}1935-1953 \\
(19 \text { years })\end{array}$ & 5475 & 288 \\
\hline \multirow{4}{*}{$I V$} & A: upswing & $1949-1968$ & $\begin{array}{c}1954-1973 \\
(20 \text { years })\end{array}$ & 5737 & 287 \\
\cline { 2 - 6 } & B: downswing & $1969-1982$ & $\begin{array}{c}1974-1987 \\
(14 \text { years })\end{array}$ & 4495 & 321 \\
\hline \multirow{3}{*}{$V$} & A: upswing & $1983-$ & $\begin{array}{c}1988-2006^{42} \\
(19 \text { years })\end{array}$ & 6077 & $320^{43}$ \\
\cline { 2 - 7 } & B: downswing & $2006^{41}$ & & & $?$ \\
\hline
\end{tabular}

Source: LLSDC. n. d. URL: http://www.llsdc.org/assets/sourcebook/sess-congress.pdf

Fig. 8. Correlation between K-wave phases and average number of the US Congress session days per year (taking the five-year lag into account, version 1)

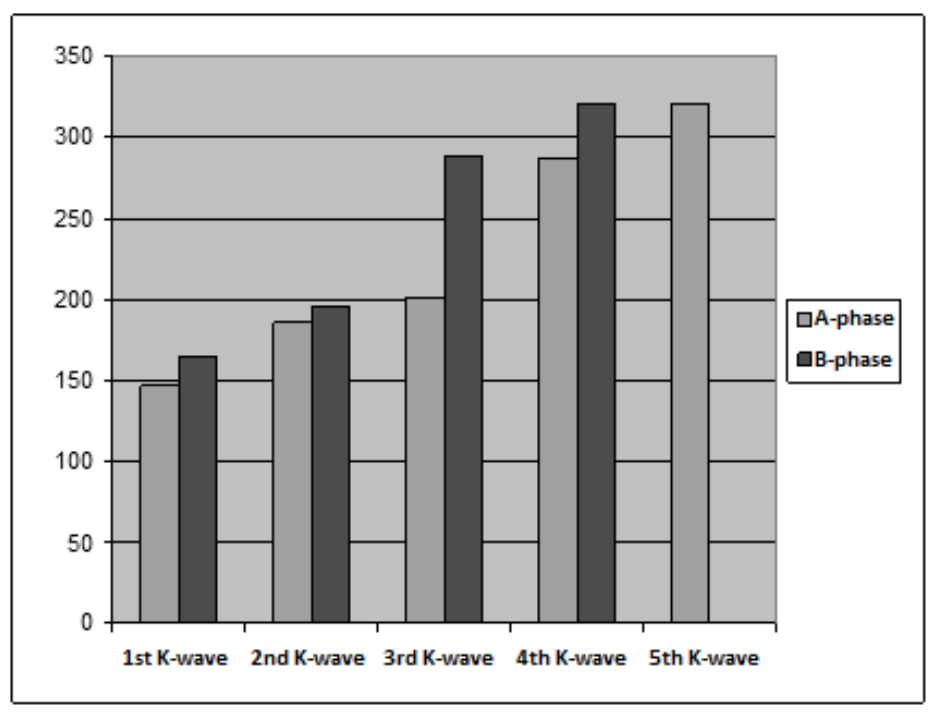

Note. The point that the average number of session days per year at B-phases is higher than at A-phases is more visible as regards the $3^{\text {rd }}$ and $4^{\text {th }} \mathrm{K}$-waves (rather than the $1^{\text {st }}$ and the $2^{\text {nd }}$ ). It appears necessary to note the following in this respect:

\footnotetext{
${ }^{41}$ In this phase we took the period preceding the 2007-2010 crisis.

${ }^{42}$ Within this phase we have taken the period preceding the start of the crisis.

${ }^{43}$ Which is less than in the B-phase of the $4^{\text {th }} \mathrm{K}$-wave. We can forecast that during the B-phase of the $5^{\text {th }} \mathrm{K}$-wave the average number of the US Congress sessions per year will be higher.
} 
1. The situation reflects the fact that since the late $19^{\text {th }}$ century governments started paying much more attention to economic problems than earlier.

2 . As regards the $2^{\text {nd }}$ wave, one should take into account that its B-phase was rather peaceful, whereas its A-phase includes the periods of the Civil War and Reconstruction of the South when the Congress had to work more intensively.

If we only consider the peaceful part of the K-wave A-phase, the distribution of the US Congress session time looks as follows:

1853-1861 - 1480 days of the US Congress sessions in nine years (on average 164.4 days per year);

1870-1878 - 1600 days of the US Congress sessions in nine years (on average 177.8 days per year).

Thus, altogether for all the peaceful years of the $2^{\text {nd }} \mathrm{K}$-wave A-phase - on average 171.1 days per year, which is substantially less than 195.2 days per year attested for the $2^{\text {nd }} \mathrm{K}$-wave B-phase;

1862-1869 (war-and-reconstruction period) - 1740 days of the US Congress sessions in eight years (on average 217.5 days per year). As we see a higher level of average annual US Congress sessions at the $2^{\text {nd }} \mathrm{K}$-wave A-phase is connected with this difficult period of the US history.

As regards the $3^{\text {rd }} \mathrm{K}$-wave, war periods are found at both A- and B-phases.

A graphic picture of this pattern is presented in Fig. 9.

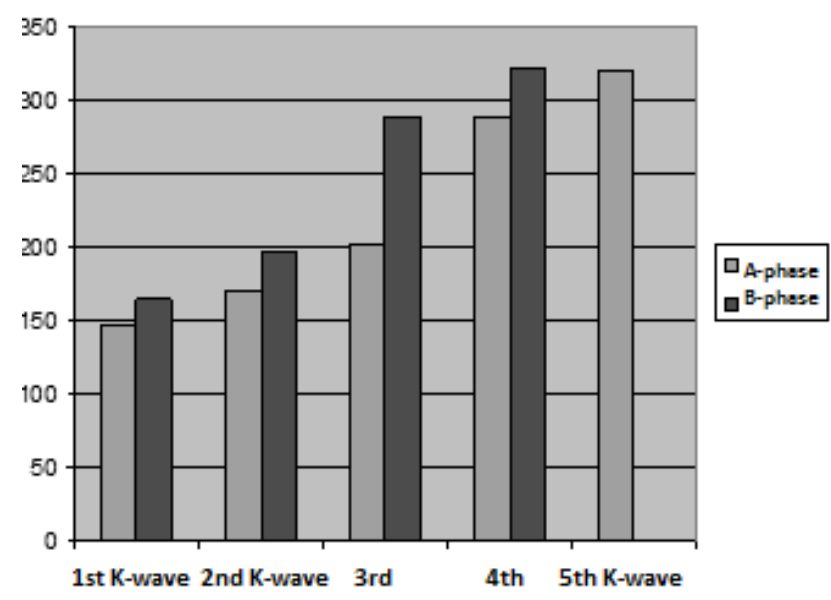

Fig. 9. Average annual number of days of the US Congress sessions in their relationship with $\mathrm{K}$-waves and their phases (taking the five-year lag into account, version 2: taking into consideration the $2^{\text {nd }} \mathrm{K}$-wave A-phase)

Note. Fig. 9 displays the relationship between the number of the US Congress sessions at the A-phases and B-phases of $\mathrm{K}$-waves with the elimination of the war-andreconstruction years (1862-1869). Here it is especially visible that within all the documented K-waves the respective society paid more attention to necessary changes during the downswing B-phases. 

Social Innovations as a Factor of K-Wave Interphase
Transitions at the Level of Individual Societies, the Level
of Intersocietal Interactions, and the World-System Level

It appears rather important to emphasize that, though the change of K-wave phases is connected with the exhaustion of the potential of respective technological paradigms, ${ }^{44}$ its immediate factors include first of all behavior of particular economic agents (including the state institutions), which is very tightly connected with psychological sets of businessmen and political elites. When development accelerates at the A-phase, this stimulates additional investment activities. In contrast, during phases of depression society is actively seeking opportunities to minimize losses, and to re-introduce the accelerating growth trend. During the past two centuries more and more forces joined the agents of economic development in their attempts to re-start the upswings; and these included government, state and interstate agencies, education institutions, ideology, science, etc. These are the activities of all those forces that lead to the eventual end of the downswing and the start of a new upswing. ${ }^{45}$

Here it appears possible to expand Schumpeter's idea (Schumpeter 1939, 1949 [1911]) regarding innovators as well as the creative destruction; many economists like this idea, but they do not appear to apply it in a sufficient way. In fact, in the innovators of all kinds of social activities during downswing phases have more opportunities to implement their innovations: politicians who promise to solve economic problems, reformers, legislators, scientists, etc. The ideas that begin to be discussed and implemented, could be expressed for a long time, limited experiments could be carried out much earlier (or in other countries), but it is during the times of difficulties when clusters of reform and change appear. The solution for the difficulties can be found - ceteris paribus in those societies where depressive manifestations of the crisis are stronger. Ultimately, innovative changes begin to work, to spread and to give effect, in particular they contribute to the diffusion of financial and technological innovations (in other words, a new innovative synthesis emerges). Thus, we should talk about innovations and innovators of all kinds, including social innovators and innovations. Thus, effective methods to counter crisis are beginning to spread, and, like technological innovations, they may be borrowed by modernizing societies with a significant delay, but in a completely ready form. The wider this process of reforms is conceptualized, the more opportunities can be found for economic growth and the longer can be the upswing. In particular,

\footnotetext{
${ }^{44}$ In the widest possible sense of this notion, i.e., the one that includes financial, social, cultural, and political technologies.

${ }^{45}$ It appears necessary to note that social innovations are not always found, or they may turn out not to be quite effective, or blind-alley innovations emerge (e.g., in Nazi Germany); in these cases crises could be especially destructive - and not only economically (as these was, e.g., observed in the case of World War II).
} 
this explains economic successes in several post-World War II European countries and Japan (economic 'miracles') in the 1950s and 1960s, as well as some modern achievements of China actively using the whole arsenal of countercyclical measures developed in Western countries. At the same time, taking into account the point that the Chinese leadership has more opportunities to effectively pursue such policies than the governments of the countries with full market economies status, the results of counter-cyclical policies in China are indeed very impressive.

Time lags. Intensification of modernization processes within the World System. But the emergence of a major social innovation (effective in combating new manifestations of depression) may not be a quick thing. Therefore, although a collision with difficulties initially causes frequently active, significant anti-crisis actions, yet they do not lead to profound changes. A considerable time must elapse before a new innovative system starts working. This may take up to ten years or even more. In the meantime, on the one hand, during the B-phase social innovations lag behind, because they are only beginning to be implemented sometime after its first third (or even later), and they can only be implemented during the second third (or later). And on the other hand, in fact, they give their real effect toward the end of the B-phase. However, early in the A-phase social innovations get implemented fully. As a result, when the upswing is already underway, the inertia of social change further accelerates the A-phase. Conversely, at the beginning of a downward phase we deal with another sort of inertia when the society is not ready to change, which, accordingly, further aggravates the B-phase.

Within the B-cluster of three J-cycles one can observe the emergence of a set of technological, financial, and social innovations, which leads to an accelerated modernization of the semi-periphery, that accelerates the A-phase upswing due to faster growth and increased demand (including the state demand). ${ }^{46}$ Gradually these innovations add up to a system, which is adopted by 'catching up' societies. This further explains the inertia force of the upswing: in the first J-cycle of the A-phase one can see belated reforms that would have to be carried out at the B-phase, while during the second J-cycle imitation reforms may be carried out.

Thus, the successful implementation of social innovations against the crisis in advanced countries during the B-phase and the transition to the A-phase is a signal for many 'catching up'/ modernizing countries. This is amplified by a certain excess of capitals in the core countries of the World System, as at B-phase those capitals are not in enough demand. Modernizing countries are beginning to implement not only technical and economic, but also social tech-

\footnotetext{
${ }^{46}$ It appears appropriate to note that many social innovations/counter-crisis technologies emerge not in the central societies of the World System but in those societies that aspire to become central.
} 
nologies. This leads to both more powerful process of modernization in the World System in the A-phase than in the B-phase, and to a more rapid growth of economically active parts of the World System, but also to a more rapid spread of impulses throughout the World System. All together this creates a new situation in the World System, which is very sensitive to the exhaustion of the potency to develop. Therefore, the crisis, which eventually captures the World System center, has an impact to some extent on all at once.

Additional note on the diffusion of technologies. During the A-phase a more active modernization of peripheral countries is usually connected with the adoption of such technologies that can be hardly characterized as the most advanced. Rather, these are technologies of the previous wave. Thus, the most advanced technologies remain in the leading countries. But the core technologies of the previous generation are moved from advanced countries (as this was observed, e.g., in the 1990s). Such outsourcing has disadvantages (structural unemployment, etc.), but it also has some pluses, since it clears the advanced countries physically from the old technologies (this is also a kind of innovation at the level of the World System). If such technologies remain and are artificially supported by the state, the leaders start losing their leading positions (as this happened to Britain with her textile and coal industries).

\section{What Limits the Length of the K-Wave A-Phases?}

Economists have long pondered over the question, 'why prosperity does not last indefinitely' (Mitchell 1913: 452, cited in Hansen 1951). And in the early $20^{\text {th }}$ century they suggested that the prosperity and decline should be explained by the processes occurring regularly within the economy itself (Mitchell 1913: 452-468, cited by: Hansen 1951). We also maintain that growth, although it is an essential feature of the industrial and post-industrial economy, does not occur automatically, but requires sustained efforts. ${ }^{47}$ The faster the growth, the more effort is required, and thus, at some point the system confronts the law of diminishing returns, that is, for each new point of growth more effort is required. Already because of this the rise cannot be infinite.

However, the question arises, why the upswing is limited to a certain period? Above we have explained the reasons for such time constraints. This section will discuss the aspects of the new restrictions, and additionally shows some aspects of the relationship of $\mathrm{K}$-waves and J-cycles.

The reasons that, as a rule, the A-phase does not last more than three or four J-cycles are connected with the following points:

- with the exhaustion of resources or growth factors (that are necessary to ensure upswing dynamics);

- with the inflated optimism about the prospects for business growth, which is also reflected in the excessive increase in the value of assets;

\footnotetext{
${ }^{47}$ Internal impulse to the growth created the desire of businessmen to increase their profits, as well as the desire of population to increase the standard of living and consumption.
} 
- with the emergence of long depression pauses in those J-cycles that are situated at the border of upswing and downswing phases of K-waves, which leads to changes of business development strategies.

In this case the first two points in K-waves and J-cycles are substantially similar, and the last point is specific only for the long-term processes, that is, for K-waves. The latter point is part of what can be called the factor of duration recessive-depressive phases of J-cycles. In our opinion, it is very important for understanding the causes of the shifts from K-wave upswings to downswings. The fact is that if crisis pauses are brief, they generally do not change dramatically business strategy vector in the direction of growth and investment. During prolonged crisis-depressive phases of J-cycles business strategies can be truly reversed.

Let us consider these reasons in detail.

\section{Exhaustion of growth factors}

The upswing weakening is due to the exhaustion of available resources (factors promoting growth) in the broadest sense of the word. We believe that during the A-phase consumption of resources for growth (outstripping their creation) is much faster. As a result, after some time, the resources are exhausted, and the upward movement of the economic inevitably slows down and stops (as, in the conditions of a certain level of technology, resources are always limited). Accordingly, at B-phases accumulation of potential resources runs ahead of their consumption.

Note that we speak about 'resources' in the widest possible sense of this word - that is about technological, financial, innovatory, social, demographic (and so on) resources both at the societal level and at the level of the World System.

In particular, important resources are needed to continue the recovery; they include new business technologies (including financial technologies), expansion of markets, removal of obstacles for exchange, trade, export, easy movement of capital; free capital themselves; unsatisfied effective demand for some important goods and services; a number of important unimplemented innovations, etc. Finally, this is the willingness of states to invest and support business processes. Within the framework of the World System these are societies that are ready to modernize, etc.

During A-phases resource consumption rates tend to be higher than during the phase of resource accumulation due to a rather simple reason: the main attention of business is attracted by the expansion of production, investment and so on, which, by definition, implies a rather high rate of resource consumption (note that these also include credit resources). ${ }^{48}$

For the emergence of additional powerful impulses qualitative changes are required. For this kind of qualitative changes the society needs major restruc-

\footnotetext{
${ }^{48}$ It reminds accelerated mining operations during the boom without intensive investment in exploration. Accordingly, the amount of proven reserves decreases.
} 
turing and the involvement of new resources that will not happen automatically, but requires considerable time.

Thus, an A-phase (upswing) gives place to a B-phase (downswing); during the B-phase one can observe not only the systemic restructuring, but also the accumulation of many resources, including both innovations (e.g., Schumpeter 1982, 1939) and such conventional resources as capital that is not invested. ${ }^{49}$

It is important to understand that after a long period of weak growth, interrupted by crises and depressions (i.e., after the B-phase), the momentum to accelerate new $K$-wave can take place only in the presence of large amounts of resources and growth factors. Synchronism in the rise is achieved because a certain set of resources is required for it, and because one innovation may lead to innovations in other areas; on the other hand, free capital contribute to the acceleration of modernization, whereas development of modernization constantly requires new capital, and so on.

The immediate impetus to the growth of a $\mathrm{K}$-wave is given, as already mentioned, at the recovery stage of one of J-cycles, and the mechanism for the transition from depression to recovery has been already described many times (see, e.g., Mitchell 1930; Hansen 1951). Thus, the mechanism has a great similarity to the transition from growth to slow down and new growth within Jcycles and $\mathrm{K}$-waves. This mechanism is associated with the rapid depletion of resources in the period of growth and boom, leading to a rapid increase in their prices, and then the accumulation of resources during the recession, until finally the abundance of resources will not push the economy to a new upsurge. But only the acceleration of the K-wave A-phase (in contrast to the transition from depression phase to phase of recovery within the J-cycle) requires qualitatively different resources: technological and social innovations, new modernizing societies, new technologies, etc.

\section{Excessive business optimism about the prospects for growth and the revaluation of assets}

Many projects and investments, which are carried out in the growth phases of Jcycle, are designed to be carried out during rather long periods of time. As stated earlier, if the recessive depressive phases are short, the processes of investment and growth do not lose momentum, nor - that is very important - psychological confidence. As a result, with a short recessive gap various projects get suspended less frequently.

As we have seen, short recessions are typical for K-wave upswing phases, when growth factors (resources) have not been exhausted yet.

However, after the first (and even more so after the second) relatively favorable J-cycle (with short phases of recession and depression) one can observe

\footnotetext{
${ }^{49}$ For example, Tugan-Baranovsky (2008 [1913]) connected economic upswing impulses precisely with this factor.
} 
in business and society the growth of optimism (the desire and courage to invest profitably), which is in opposition with the diminishing growth resources.

In the A-phase, the revaluation of assets (stocks, real estate, commodities, etc.) is also associated with a lengthy economic growth and bullish price trend, which leads to excessive demand for some resources, large scale speculation and the emergence of 'bubbles'. Dramatic overestimation of the value of assets is connected with the increasing demand for resources and the growth of unjustified assumptions that asset prices will rise further. In fact, the situation is evolving in a pyramid-like way (whereas the 'pyramid' is becoming more and more unstable every month). Below we will see that it is at the moment of the greatest depletion of resources (and at the same time the greatest weakening of the growth potential - both occur by the end of the last J-cycle of the A-phase) the unreasonable optimism among the businessmen about the future growth in asset prices is peaking. ${ }^{50}$

It is clear that, as a result of the collapse, the asset revaluation occurs with a minus sign (which is especially noticeable during the acute phase of the crisis).

\section{Long depression pause emerging within border J-cycles and the change of development strategy}

As we have seen, the duration of a recessive-depressive phases of J-cycles is important for understanding the dynamics of K-wave phase changes. Meanwhile, after two (sometimes three) J-cycles in which these phases have been short, in the third (sometimes fourth) A-phase J-cycle the duration of the recessive-depressive period qualitatively increases. Thus, the respective J-cycle becomes a landmark between the A- and B-phases of the respective K-wave.

An increase in the recessive-depressive phases is due to the coincidence of extreme values of divergent trends. On the one hand, the value of assets and the level of revaluation reach their peaks, and the optimism of businessmen and society as a whole is at apogee; on the other hand - the value of resources available for growth (growth factors) reaches a minimum.

Simultaneously, in society and economy there are too many unresolved issues. As a result, the recession acquires a very large scale, and attempts to overcome the crisis and continue to grow do not work out. And as there are not enough resources to resume the upward movement, there is an insufficient momentum to continue the A-phase upswing.

Prolongation of recession and depression phases inevitably leads to changes in business and social strategies. ${ }^{51}$ Of course, there is a significant difference

\footnotetext{
${ }^{50}$ For example, Hansen (1951) demonstrates in a rather convincing way that during the Great Depression it became perfectly clear how completely resources of new construction had been used, which was one of the drivers of the rise in the 1920s. But the peak of the construction was achieved long before 1929, about 1925-1926. High demand for the construction of real estate at this time is explained by the fact that during the World War II, civil construction was almost entirely frozen.

${ }^{51}$ On the society's strategy and its search for counter-crisis social innovations see above.
} 
between a crisis that continues for a few months, and a depression that continues for several years. It is necessary to adapt to the new situation, and hence to reduce costs and volumes, while starting to rebuild the business and seek new ways for its development. Projects are suspended, investment declines, demand falls, prices (at least on revalued assets) are also falling, capitals are not invested, etc. Thus, there is a feedback loop: the longer the recessive period, the less investment, and vice versa - the less investment, the longer the recession. Then a new rise may start, but it will be of a different type (that is characteristic of J-cycles in the downward phase). To maintain upward trend after a fairly prolonged stagnation and depression a society needs an appropriate big enough momentum that cannot appear from nowhere (especially without the presence of effective anti-crisis social innovations).

Thus, the question about the reasons for a certain duration of the A-phase of a $K$-wave is largely related to the question of the causes of sudden lengthening of depressive phases of the crisis of J-cycles (at the end of the A-cluster of those cycles). And this undoubtedly further demonstrates the close connection between the K-waves and J-cycles.

It is also clear why during the B-phase the economy cannot gain earlier momentum. Firstly, it takes time to develop counter-crisis measures. Secondly, it is necessary to accumulate a sufficient amount of growth factors, including breakthrough technological innovations. Thirdly, you need a push to change the business strategy. Thus, a feedback loop gets established: weak expansions inactive strategy - lack of investment - no impulses for a strong recovery weak expansions, and so on. And this feedback loop may operate for a quite long period of time.

\section{THE DIMENSION OF THE WORLD SYSTEM}

Modernization and World-System Socioeconomic Crises

Tensions of intensive modernization; relationship of the $K$-wave A-phases to semi-peripheral economic and social crises, as well as wars of certain types

During upswings of the K-wave peripheral and semi-peripheral economic and political crises occur more frequently. Recall that already Kondratieff (1935: 111) noted that 'it is during the period of the rise of the long waves, i.e., during the period of high tension in the expansion of economic forces, that, as a rule, the most disastrous and extensive wars and revolutions occur'.

This point requires further explanation. One should take into consideration that: a) semi-peripheral modernizing countries tend to borrow social innovations rather fast; b) but often they do not have a sufficient basis for the 'digestion' of such innovations (and social innovation can be for them altogether alien). The result is what can be called 'crises of modernization', not only ex- 
pressed in economic crises, but also in revolutions and even wars. ${ }^{52}$ The Asian crisis of 1997 was largely such a modernization crisis. Revolutions of the early $20^{\text {th }}$ century can also be considered as such crises.

As for the wars, of course, not all, but some of them may well be attributed to a reaction to the rapid modernization, as well as manifestations of the restructuring of the World System. In particular, major wars were connected with the formation of large nation-states in Europe in the 1850s-1870s (Italy, Germany). The war factor will be discussed in more detail below.

\section{World-System Crises and Obstacles for the Emergence of the World-System Innovations. World-System Innovations and their Delays}

The increase in the World System modernization (combined with technological and social innovations) leads to the expansion and reconfiguration of the World System, that after some time creates the need for a change in relations within the World System. If the latter is delayed, then crises emerge, and those crises cannot be overcome within individual countries and through individual social innovations. In this case, the World System confronts a series of deep crises (as was observed in the period between 1914 and 1945).

Thus, the development of the World System and modification of K-waves are closely interdependent. Accordingly, some phase of K-waves appears as special, as to exit from the crisis at some stage of the K-wave world-system solutions are necessary, and such innovations may be delayed. In particular, during the third wave (1890-1940s) one could observe a profound transformation of the World System, so the crises of its downswing acquired a militarypolitical form and generally were the most profound.

Already in the early $20^{\text {th }}$ century the World System encompassed, in fact, the entire Globe. The innovations at the level of individual countries were not sufficient (partly because of very strong protectionism, military and colonial rivalries). There were also very different political regimes. Hence, the further development required new world-systemic innovations in relations between the countries. However, at the level of the world-system the old ways of solving conflicts and problems were still operating and new ones did not yet succeed easily. As a result, the restructuring of the World System proceeded in the old military and revolutionary way.

Only after the World War II, it became apparent that it is necessary to look for new innovative solutions at the World System level. But there was no immediate feedback since there was no generally accepted model or supranational

\footnotetext{
${ }^{52}$ They become even more dangerous if coincide with rapid population growth that is so characteristic of the period of the escape from the Malthusian trap (for more details on the modernization crises see Korotayev, Zinkina, Kobzeva et al. 2011; Korotayev, Khaltourina, Malkov et al. 2010; Korotayev, Khaltourina, Kobzeva et al. 2011; Grinin, Korotayev, and Malkov 2009, 2010; Grinin 2010a, 2011b).
} 
bodies, and there were large differences between metropolises and colonies. As a result, some countries tried to counteract the crisis phenomena that are characteristic for the World System as its whole in their own ways. At some stage there was a major contradiction: on the one hand, the interactions became very strong and more interdependent, and on the other - clashes between participants became sharper, some development models and social innovations (that were used by some states) were dangerous to others. As a result, the crisis became more and more acute. Ultimately, the World-System contradictions escalated into the huge World War II. Only in this way the world community finally managed to establish the leading model of development and common patterns of behavior in world markets at least in the main part of the World System, and in some major countries - to conduct the necessary social changes that are important for economic development around the world. In this, war gradually ceased to be the leading form of reconstruction of the World System.

Today the situation is rather similar to the one observed in the early $20^{\text {th }}$ century. A serious reconfiguration of the World System is forthcoming, which implies a number of significant world-system innovations in the near future. However, the nature of those innovations is not clear yet. This may lead to the prolongation of depressive processes and aggravation of crisis phenomena (needless to mention that the military forms of the search for such innovations should be excluded nowadays).

\section{How does the K-Wave Synchronicity in the World System Emerge?}

To some extent, it reminds growth-generating mechanism in national economies, where growth points emerge, and those growth points - if they are powerful - pull the whole economy. On the other hand, we observe here the emergence of such states that act as locomotives creating momentum for all. To a certain extent this is reflected in the theory of leading sectors and leading economies in the application to the World System (Modelski 1987; Modelski and Thompson 1996; Thompson 1990, 2000; Rasler and Thompson 1994; Rennstich 2002). The leading sector leads a respective national economy, whereas the respective leading economy leads the world economy. It is important that new counter-crisis technologies emerge, which are also gradually adopted; finally the states develop some common solutions that may evolve into the World System solutions. Downswing signals are transmitted in a similar way.

Mechanism of relatively rapid momentum transfer from certain World System zones to its other areas is determined by the mechanisms of the World System economic relations: rising/falling world trade (including the effect of changes in import/export duties); movement of global capital (and the formation of its new centers); currency (gold) fluctuations ; export/import of technology (patents); international agreements; fluctuations in the prices of raw 
materials, fuel, food and other commodities. (see examples in Grinin 2011a, 2013b; Korotayev, Zinkina, Bogevolnov, and Malkov 2011). Regardless of whether that was due to growth in certain countries, these mechanisms may well be changing development trends in the World System periphery or semiperiphery, if they have been already changed in the World System core.

If we take the transmission of impulses from the leading countries to the less developed or less actively developing ones throughout the K-wave, the connection with the J-cycles becomes more visible. During the period of one J-cycle (7-11 years) advantages of new technologies, organizational arrangements, and other achievements (that have appeared in the leading country or countries) become more obvious. The second cycle starts with great intensity the modernization of a large number of countries. The third cycle extends modernization, but at this level there are already difficulties associated with the complexity of sharing as well as a fall in the rate of profit, and - very important - especially in the transformation of institutions and relationships both within individual countries and across the World System.

\section{GENERAL CHARACTERISTICS OF K-WAVE EVOLUTION, FACTORS, MECHANISMS, AND INDICATORS}

\section{How and Why do the Main K-Wave Dynamics Indicators Change?}

General direction of changes

We have examined how K-waves and J-cycles interact. Let us now see how and why the main $\mathrm{K}$-wave dynamics indicators change.

As has already been mentioned above, Kondratieff himself and many researchers after him believed that the main indicators of the upswing/downswing dynamics within the $\mathrm{K}$-waves are associated with directions of price trends. But in recent decades this role is rather played by the relative GDP growth rate dynamics (Mandel 1975, 1980; see also Kuczynski 1980; Bieshaar and Kleinknecht 1984; Kleinknecht 1987; Poletaev and Saveljeva 1993). Some researchers use other indicators, including class struggle indices.

This inconsistency adds complexity to the measurement of K-waves: how can we talk about the long process of K-wave alteration, if the figures are different, and sometimes contradicting each other? K-waves in the price dynamics have the most recognized empirical support (see, e.g., Gordon 1978: 24; Van Ewijk 1982; Cleary and Hobbs 1983; Berry 1991, etc.). But the logic of Kwaves in price dynamics disappeared after the World War II, as then period prices tend to rise even during downswing phases. ${ }^{53}$

At this stage, the attempts to detect K-wave dynamics in the global GDP (and similar indicators) have yielded rather conflicting results. In particular, empirical tests of some researchers did not confirm the presence of K-waves in the world industrial dynamics (see, e.g., van der Zwan 1980: 192-197; Chase-

\footnotetext{
${ }^{53}$ However, it is possible that it will remain, if we measure the current prices in the prices of gold.
} 
Dunn and Grimes 1995: 407-409). One of the main reasons is, of course, insufficient data on the pace of economic growth in earlier periods. But more importantly, that the data that do exist, cannot demonstrate the existence of global long-wave oscillations until the middle of the $19^{\text {th }}$ century (see, e.g., Poletaev and Saveljeva 1993: 221; Korotayev and Tsirel 2010a). We can assume that this is not accidental, as rising prices and GDP growth can develop in certain periods in different directions (see our analysis of the causes of price trends and changing trends in the increases/decreases of the profit rates below). Similarly, there are some doubts that K-waves can be traced in the dynamics of global GDP in the period up to 1870 , though in this period they had been apparently present in the economic macrodynamics of the West (Korotayev and Tsirel 2010a, 2010b, 2010c; Grinin and Korotayev 2010b: 240).

Nevertheless, our analysis of the dynamics of K-waves for over two hundred years suggests that within this apparent incompatibility one may still trace some organic link, if we assume that the factors that define K-wave phases change (at least, according to their importance) in a natural way. K-waves change their manifestations in connection with the development of industrial production, as well as with the expansion of the World System and the World System links. In addition, the role of the state grows. It is worth noting that J. J. van Duijn puts forward a very plausible hypothesis, stating that long waves in economic growth emerged in the second half of $19^{\text {th }}$ century, replacing long waves in price movements (van Duijn 1983: 91).

If we accept the idea of natural changes in the K-wave factors, it allows us to move to an organic synthesis of all the major theories explaining $\mathrm{K}$-waves through monetary, technological, investment, external and military factors. Note that during the A-phase of the $1^{\text {st }} \mathrm{K}$-wave the upward trend in prices was mostly caused by the war (in fact, it lasted for more than two decades - from 1792 to 1815) and the continental blockade policy. But then we observe a gradual transition from exogenous factors generating long waves to endogenous trends related to innovation, large investments and the alteration of technological paradigms.

This also accounts for contradictions of the upswing and downswing phases of the $1^{\text {st }} \mathrm{K}$-wave connected with the transition from one type of reasons determine price fluctuations, to another - namely the replacement of purely external factors with a symbiosis of internal factors associated with the growth of labor productivity with external factors. This may explain the meaning of a rather strange initial assertion when the phase associated with endless Napoleonic wars is declared upward, and the next phase (associated with the industrial revolution, [see Grinin 2007a], the most powerful economic restructuring and a huge increase in productivity) is declared to be downward.

But of course, such a change of the driving forces of long-term trends could not be either rapid or complete. During the downward phase of the first 
K-wave changes were really severe in only one country (Great Britain), but this could not change completely the trend towards lower prices in Europe, which was also caused by a very rapid increase in labor productivity, reducing production costs of manufactured products. But already the next K-wave was caused not only by external factors (wars and expansion of gold production), but also by a change in the global trading system (the transition to the principles of free trade). This eliminated the narrowness of foreign markets and led to powerful investments in many different countries. We also note the emergence of a more complex system of industry (heavy and light) and the creation of new transport as well as information and communication technologies (railroads and telegraph).

On the one hand, the transition to the $2^{\text {nd }} \mathrm{K}$-wave A-phase precisely in the early 1850 was to a certain extent a contingency since it coincided with the discovery of gold deposits in California and Australia, which gave a powerful upward momentum. If we take the period between 1814 and 1847, then we would not have been surprised if this phase had started, say, in 1842 and a long upswing had begun. This upswing actually started and, in particular, due to expectations of demand on the part of the Chinese market, so that there was even an acute shortage of workers (see, e.g., Tugan-Baranovsky 2008 [1913]: 122), but the famine of $1845-1846$ suspended it. ${ }^{54}$ And during this time opportunities for new growth had improved.

Note that the rise provides sufficiently large reserves to become really long if it is accompanied by the expansion of the World System's core (and, hence, semi-periphery's catch-up).

It seems that the price changes as the main K-wave indicator started to be replaced by the fluctuations in economic growth rates sometime in the early $20^{\text {th }}$ century. This, in particular, is reflected in the competition of Britain and Germany. Finally, this became clear after the World War I and the postwar crisis of 1920, and it is no accident that in the period preceding the Great Depression, prices barely rose (see Grinin and Korotayev 2010b: 123-125; Haberler 2008: 9-10, 28 for more detail), which even was a cause of some forecast errors. Such a radical change in the oscillation factors coincided (but not coincidentally): a) with an almost complete expansion of the World System; b) with the change of its leader; c) the weakening of the gold standard; and d) the fact that the industry, including the heavy industry, began to play a decisive role in the pace and direction of economic growth.

Change of the role of the state

During the $19^{\text {th }}$ century the role of the state changed significantly: it stops being neutral, as states become more and more interested in high economic growth rates (some states showed interest in the development of trade and industry quite

\footnotetext{
${ }^{54}$ This is evidenced, e.g., by the following fact: in $1845-1847$ the share of food in the British import grew from $3 \%$ to $50 \%$ (Trakhtenberg 1963: 155).
} 
long ago, in particular, parliamentary commissions in England analyzed reasons for the decline of industry during the 1825 crisis, see e.g., Tugan-Baranovsky 2008 [1913]). Prior to this, states at best cared for maintaining stability of the currency and government securities, and partly for the construction of communications. We should also note the state's role in the development of military technology and military orders. Starting from the Great Depression the economic growth became one of the main concerns of the state.

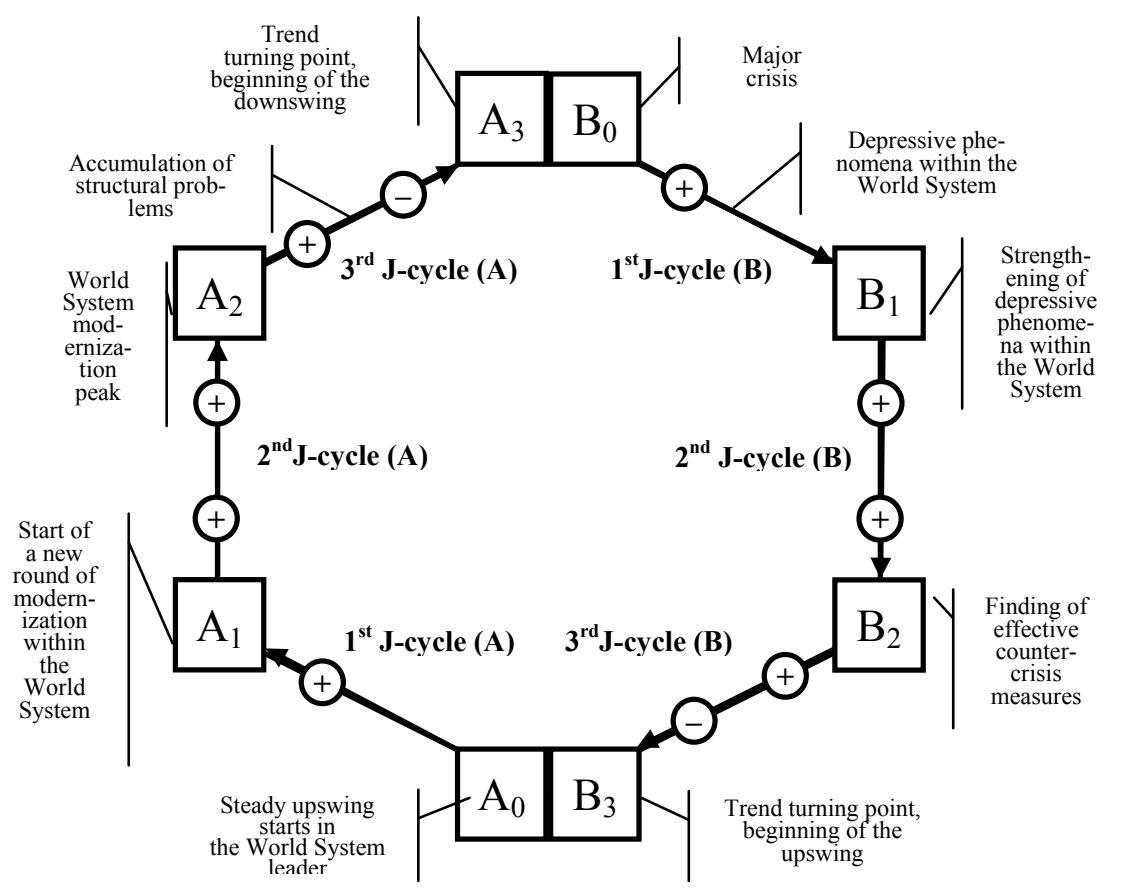

Fig. 10. Correlation between Kondratieff waves and Juglar cycles. Version 1 


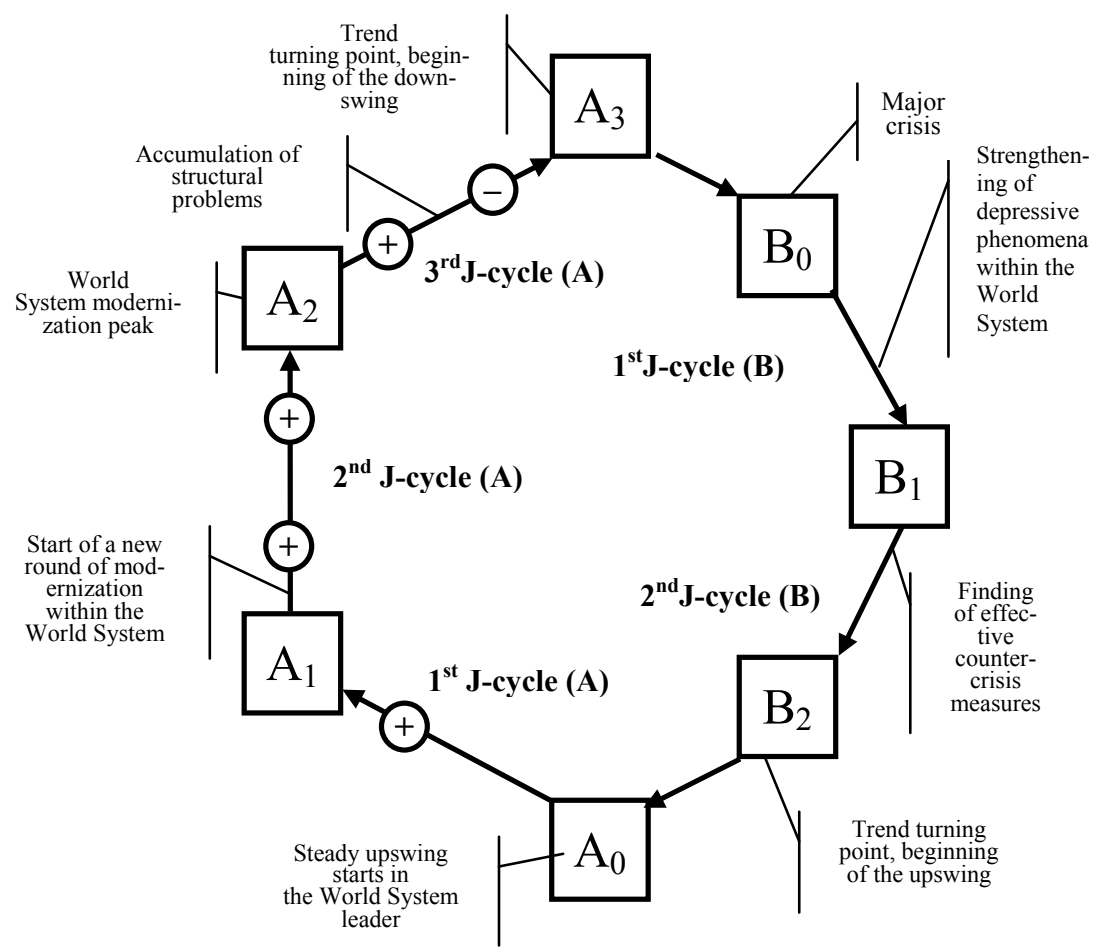

Fig. 11. Correlation between Kondratieff waves and Juglar cycles. Version 2

\section{References}

Abel A. B., and Bernanke B. S. 2008. Macroeconomics. $6^{\text {th }}$ ed. New York: Addison Wesley. In Russian (Абель Э. Б., Бернанке Б. С. Макроэкономика. 5-е изд. СПб.: Питер).

Abramovitz M. 1961. The Nature and Significance of Kuznets Cycles. Economic Development and Cultural Change 9(3): 225-248.

Akaev A. A., Rumyantseva S. Yu., Sarygulov A. I., and Sokolov V. N. 2011. Economic Cycles and Economic Development. St. Petersburg: Technical University. In Russian (Акаев А. А., Румянцева С. Ю., Сарыгулов А. И., Соколов В. Н. Экономические ииклы и экономический рост. СПб.: Изд-во Политехн. ун-та).

Akaev A., Fomin A., Tsirel S., and Korotayev A. 2010. Log-Periodic Oscillation Analysis Forecasts the Burst of the 'Gold Bubble' in April-June 2011. Structure \& Dynamics 5(1): 3-18. 
Akaev A., Sadovnichy V., and Korotayev A. 2011. Explosive Rise in Gold and Oil Prices as a Precursor of a Global Financial and Economic Crisis. Doklady Akademii Nauk (Mathematics) 83(2): 1-4.

Akaev A., Sadovnichy V., and Korotayev A. 2012. On the Dynamics of the World Demographic Transition and Financial-Economic Crises Forecasts. The European Physical Journal 205: 355-373.

Avramov R. 1992. The Theory of Long Waves: Historical Context and Methodological Problems. Voprosy Ekonomiki 10: 63-68. In Russian (Аврамов Р. Теория длинных волн: исторический контекст и методологические проблемы. Bonpocbl экономики 10: 63-68).

Berry B. J. L. 1991. Long Wave Rhythms in Economic Development and Political Behavior. Baltimore, MD: Johns Hopkins University Press.

Berry J. L., and Dean J. 2012. Long Wave Rhythms: A Pictorial Guide to 220 Years of U.S. History, with Forecasts. Kondratieff Waves. Dimensions and Prospects at the Dawn of the $21^{\text {st }}$ Century / Ed. by L. Grinin, T. Devezas, and A. Korotayev, pp. 107-119. Volgograd: Uchitel.

Besomi D. 2005. Clément Juglar and the Transition from Crises Theory to Business Cycle Theories. Paper prepared for a Conference on the Occasion of the Centenary of the Death of Clement Juglar. Paris, 2 December.

Bieshaar H., and Kleinknecht A. 1984. Kondratieff Long Waves in Aggregate Output? An Econometric Test. Konjunkturpolitik 30(5): 279-303.

Blaug M. 1985. Economic Theory in Retrospect. $4^{\text {th }}$ ed. Cambridge, UK: Cambridge University Press.

Burns A. F., and Mitchell W. C. 1946. Measuring Business Cycles. New York: National Bureau of Economic Research.

Cassel G. 1925. Theory of Conjunctures. Moscow: TsUP VSNKh. In Russian (Кассель Г. Теория конъюнктур. М.: Тип. ЦУПВСНХ).

Cassel G. 1932. Theory of Social Economy. New York: Harcourt.

Chase-Dunn Ch., and Grimes P. 1995. World-Systems Analysis. Annual Review of Sociology 21: 387-417.

Cleary M. N., and Hobbs G. D. 1983. The Fifty Year Cycle: A Look at the Empirical Evidence. Long Waves in the World Economy / Ed. by Chr. Freeman, pp. 164-182. London: Butterworth.

Delbeke J. 1987. Long-Term Trends in Belgian Money Supply, 1877-1984. The LongWave Debate / Ed. by T. Vasko, pp. 313-325. Berlin: Springer-Verlag.

Devezas T. 2012. The Recent Crisis under the Light of the Long Wave Theory. Kondratieff Waves. Dimensions and Prospects at the Dawn of the $21^{\text {st }}$ Century / Ed. by L. Grinin, T. Devezas, and A. Korotayev, pp. 138-175. Volgograd: Uchitel.

Dornbusch R., and Fisher S. 1997. Macroeconomics. Moscow: MSU. In Russian (Дорбуш Р., Фишер С. Макроэкономика. М: МГУ).

Duijn J. J. van. 1983. The Long Wave in Economic Life. Boston: Allen and Unwin. 
Ewijk C. van. 1982. A Spectral Analysis of the Kondratieff Cycle. Kyklos 35(3): 468499.

Fischer S., Dornbusch R., and Schmalensee R. 1988. Economics. New York: McGrawHill.

Fridman M. 2002. Basic Concepts of Monetarism. Moscow: Teis. In Russian (Фридман М. Основы монеаризма. М.: ТЕИС).

Gellner E. 1983. Nations and Nationalism. Oxford: Blackwell.

Glaziev S. Yu. 2009. Global Economic Crisis as a Process of Technological Shifts. Voprosy Ekonomiki 3: 26-32. In Russian (Глазьев С. Ю. Мировой экономический кризис как процесс смены технологических укладов. Вопросы экономики 3: 26-32).

Goldstein J. 1988. Long Cycles: Prosperity and War in the Modern Age. New Haven, CT: Yale University Press.

Gordon D. M. 1978. Up and Down the Long Roller Coaster. U.S. Capitalism in Crisis / Ed. by B. Steinberg, pp. 22-34. New York: Economics Education Project of the Union for Radical Political Economics.

Grinin L. E. 2003. Productive Forces and Historical Process. $2^{\text {nd }}$ ed. Volgograd: Uchitel. In Russian (Гринин Л. Е. Производительные силь и исторический проиесс. Изд. 2-е. Волгоград: Учитель).

Grinin L. E. 2006a. Periodization of History: A Theoretic-Mathematical Analysis. History \& Mathematics: Analyzing and Modeling Global Development / Ed. by L. Grinin, V. de Munck, and A. Korotayev, pp. 10-38. Moscow: KomKniga/URSS.

Grinin L. E. 2006b. Methodological Foundations of Periodization of History. Filosofskiye Nauki 8: 117-123. In Russian (Гринин Л. Е. Методологические основания периодизации истории. Философские науки 8: 117-123).

Grinin L. E. 2006c. Methodological Foundations of Periodization of History. Filosofskiye Nauki 9: 127-130. In Russian (Гринин Л. Е. Методологические основания периодизации истории. Философские науки 8: 117-123).

Grinin L. E. 2007a. Production Revolutions and Periodization of History: A Comparative and Theoretic-Mathematical Approach. Social Evolution and History 6(2): 75-120.

Grinin L. E. 2007b. Production Revolutions and the Periodization of History. Herald of the Russian Academy of Sciences 77(2): 150-156.

Grinin L. E. 2008. Unwanted Child of Globalization. Notes about Crisis. Age of Globalization 2: 46-53. In Russian (Гринин Л. Е. Нежеланное дитя глобализации. Заметки о кризисе. Век глобализаџии 2: 46-53).

Grinin L. E. 2009a. Global Crisis as the Crisis of Overproduction of Money. Philosofiya i obschestvo 1: 5-32. In Russian (Гринин Л. Е. Глобальный кризис как кризис перепроизводства денег. Философия и общество 1: 5-32).

Grinin L. E. 2009b. Modern Crisis: New Lines and Classics of Genre. Istoria i sovremennost 1: 3-32. In Russian (Гринин Л. Е.Современный кризис: новые черты и классика жанра. История и современность 1: 3-32). 
Grinin L. E. 2009c. Psychology of Economic Crises. Istoricheskaya psikhologiya $i$ sotsiologiya istorii 22: 75-99. In Russian (Гринин Л. Е. Психология экономических кризисов. Историческая психология и сочиальная история 2: 75-99).

Grinin L. E. 2009d. Will the Global Crisis Lead to Global Changes? Vek globalizatsii 2: 117-140. In Russian (Гринин Л. Е. Приведет ли глобальный кризис к глобальным изменением? Век глобализации 2: 117-140).

Grinin L. E. 2010a. Malthusian-Marxian Trap and the Russian Revolutions. History and Mathematics. On the Causes of the Russian Revolution / Ed. by L. E. Grinin, A. V. Korotayev, S. Yu. Malkov, pp. 368-427. Moscow: LKI/URSS. In Russian (Гринин Л. Е. Мальтузианско-марксова «ловушка» и русские революции. История и математика. О причинах Русской револючии / Ред. Л. Е. Гринин, А. В. Коротаев, С. Ю. Малков, с. 198-224. М.: ЛКИ/URSS).

Grinin L. E. 2010b. Which Global Transformations would the Global Crisis Lead To? Age of Globalization 2: 31-52.

Grinin L. E. 2011a. Chinese Joker in the World Pack. Journal of Globalization Studies 2(2): 7-24.

Grinin L. E. 2011b. Malthusian and Modernization Traps. The problems of Economic History: Theory and Practice. Professorial Collection of Scientific Articles devoted to the $60^{\text {th }}$ Anniversary of S. A. Nefedov / Ed. by V. V. Zapariy, pp. 95-119. Ekaterinburg: UMTs-UPI. In Russian (Гринин Л. Е. Мальтузианские и модернизационные ловушки. Проблемы экономической истории: теория и практика. Профессорский сборник научных статей, посвященный 60-летию С. А. Нефедова I Ред. В. В. Запарий, с. 95-119. Екатеринбург: ООО «Издательство УМЦ-УПИ).

Grinin L. E. 2012. Kondratieff (K-) Waves, Technological Ways and Theory of Production Revolutions. Kondratieff Waves: Aspects and Prospects/ Ed. by A. A. Akaev, R. S. Greenberg, L. E. Grinin, A. V. Korotayev, S. Yu. Malkov, pp. 222-262. Volgograd: Uchitel. In Russian (Коротаев А. В., Гринин Л. Е. Кондратьевские волны технологические уклады и теория производственных революций. Кондратьевские волны: аспекты и перспективы / Ред. А. А. Акаев, Р. С. Гринберг, Л. Е. Гринин, А. В. Коротаев, С. Ю. Малков, с. 222-262. Волгоград: Учитель).

Grinin L. E. 2013a. Dynamics of Kondratieff Waves in the Light of Theory of Production Revolutions. Kondratieff Waves: Palette of Views/ Ed. by L. E. Grinin, A. V. Korotayev, S. Yu. Malkov, pp. 31-83. Volgograd: Uchitel. In Russian (Гринин Л. Е. Динамика кондратьевских волн в свете теории производственных революций. Кондратьевские волны: палитра взглядов / Ред. Л. Е. Гринин, А. В. Коротаев, С. Ю. Малков, с. 31-83. Волгоград: Учитель).

Grinin L. E. 2013b. The Tiger and the Dragon. Development Models and Perspectives of India and China. Journal of Globalization Studies 4(1): 5-31.

Grinin L. E., and Korotayev A. V. 2010a. Will the Global Crisis Lead to Global Transformations? 1. The Global Financial System: Pros and Cons. Journal of Globalization Studies 1(1): 70-89.

Grinin L. E., and Korotayev A. V. 2010b. Will the Global Crisis Lead to Global Transformations? 2. The Coming Epoch of New Coalitions. Journal of Globalization Studies 1(2): 166-183. 
Grinin L. E., and Korotayev A. V. 2012. Global Crisis in Retrospective. Brief History of Rises and Crises: FromFrom Lycurgus to Alan Greenspan. $2^{\text {nd }}$ Ed. Moscow: Librocom/URSS. In Russian (Гринин Л. Е., Коротаев А. В. Глобальный кризис 8 ретроспективе. Краткая история подъемов и кризисов: от Ликурга до Алана Гринспена. 2-е изд. М.: Либроком/URSS).

Grinin L. E., and Korotayev A. V. 2013. Nikolai Kondratieff. Life, Destiny, Heritage. Kondratieff Waves: Palette of Views / Ed. by L. E. Grinin, A. V. Korotayev, and S. Yu. Malkov, pp. 9-21. Volgograd: Uchitel. In Russian (Гринин Л. Е., Коротаев А. В. Николай Кондратьев. Жизнь. Судьба. Наследие. Кондратьевские волны: палитра взглядов / Ред. Л. Е. Гринин, А. В. Коротаев, С. Ю. Малков, c. 9-22. Волгоград: Учитель).

Grinin L., Devezas T., and Korotayev A. (Eds.) 2012. Kondratieff Waves. Dimensions and Prospects at the Dawn of the $21^{\text {st }}$ Century. Volgograd: Uchitel.

Grinin L. E., Korotayev A. V., and Malkov S. Yu. 2009. Mathematical Models of the Socio-Demographic Cycles and Escape from the Malthusian Trap. Some Possible Directions for Further Development. The problems of Mathematical History: Mathematical Modelling of Historical Processes / Ed. by G. G. Malinetsky, A. V. Korotayev, pp. 78-117. Moscow: Librocom. In Russian (Гринин Л. Е., Коротаев А. В., Малков С. Ю. Математические модели социально-демографических циклов и выхода из «мальтузианской ловушки»: некоторые возможные направления дальнейшего развития. Проблемы математической истории: Математическое моделирование исторических процессов / Ред. Г. Г. Малинецкий, А. В. Коротаев, с. 78-117. М: Книжный дом «Либроком»).

Grinin L. E., Korotayev A. V., and Malkov S. Yu 2010. A Mathematical Model of Juglar Cycles and the Current Global Crisis. History \& Mathematics. Processes and Models of Global Dynamics / Ed. by L. Grinin, P. Herrmann, A. Korotayev, and A. Tausch, pp 138-187.Volgograd: Uchitel.

Grinin L. E., Korotayev A. V., and Tsirel S. V. 2011. Cycles of the Modern WorldSystem's Development. Moscow: Librocom/URSS. In Russian (Гринин Л. Е., Коротаев А. В., Цирель С. В. Цикль развития современной Мир-Системы. М.: ЛИБРОКОМ/ URSS).

Grinin L. E., Malkov S. Yu., and Korotayev A. V. 2009. Mathematical Model of Medium-Term Economic Cycle. Forecast and Modeling of Crises and World Dynamics / Ed. by V. A. Sadovnichiy, A. A. Akaev, G. G. Malinetsky, A. V. Korotayev, pp. 292-304. Moscow: Librocom/URSS. In Russian (Гринин Л. Е., Малков С. Ю., Коротаев А. В. Математическая модель среднесрочного экономического цикла. Прогноз и моделирование кризисов и мировой динамики / Ред. В. А. Садовничий, А. А. Акаев, Г. Г. Малинецкий, А. В. Коротаев, с. 292-304. М.: ЛИБРОКОМ/URSS).

Grinin L. E., Malkov S. Yu., and Korotayev A. V. 2010. Mathematical Model of Medium-Term Economic Cycle and Current Global Crisis. History \& Mathematics: Evolutional Historical Macrodynamics / Ed. by S. Yu. Malkov, L. E. Grinin, and A. V. Korotayev, pp. 233-284. Moscow: LIBROCOM. In Russian (Гринин Л. Е., Малков С. Ю., Коротаев А. В. Математическая модель среднесрочного экономического цикла и современный глобальный кризис. История и Матема- 
тика: Эволюиионная историческая макродинамика / Ред. С. Ю. Малков, Л. Е. Гринин, А. В. Коротаев, с. 233-284. Москва: Книжный дом «ЛИБРО$\mathrm{KOM} \gg)$.

Grinspen A. 2009. Epoch of Shock. The Problems and Prospects of the World Financial System. $2^{\text {nd }}$ ed. Moscow: Alpina Business Books. In Russian (Гринспен A. Эпоха потрясений: Проблемы и перспективы мировой финансовой системы. Изд. 2-е. М.: Альпина Бизнес Букс).

Haberler G. 1964 [1937]. Prosperity and Depression. Theoretical Analysis of Cyclical Movements. Cambridge, MA: Harvard University Press.

Haberler G. 2008. Prosperity and Depression. Theoretical Analysis of Cyclical Movements. Chelyabinsk: Socium. In Russian (Хаберлер Г. Проиветание и депрессия. Теоретический анализ цииклических колебаний. Челябинск: Социум).

Hansen, A. H. 1951. Business Cycles and National Income. New York: W. W. Norton. In Russian (Хансен Э. Экономические ичикль и национальный доход. М.: Изд-во ин. лит-ры).

von Hayek F. A. 1931. Prices and Production. London: Routledge.

von Hayek F. A. 1933. Monetary Theory and the Trade Cycle. London: Jonathan Cape.

Hawtrey R. G. 1926. Monetary Reconstruction. $2^{\text {nd }}$ ed. London: Longmans.

Hawtrey R. G. 1928. Trade and Credit. $2^{\text {nd }}$ ed. London: Longmans.

Hicks J. R. 1946 [1939]. Value and Capital: An Inquiry into Some Fundamental Principles of Economic Theory. Oxford: Clarendon Press.

Hicks J. R. 1993. Cost and Capital. Moscow: Progress. In Russian (Хикс Дж. Р. Стоимость и капитал. М.: Прогресс).

Hilferding R. 1981 [1910]. Finance Capital. A Study of the Latest Phase of Capitalist Development. London: Routledge.

Hilferding R. 1922. Finance Capital. A Study of the Latest Phase of Capitalist Development. Moscow - Leningrad.

Huerta de Soto J. 2006. Money, Bank Credit, and Economic Cycles. Auburn, AL: Ludwig von Mises Institute.

Husson M., and Louca F. 2012. Late Capitalism and Neo-Liberalism - A Perspective on the Current Phase of the Long Wave of Capitalist Development. Kondratieff Waves. Dimensions and Prospects at the Dawn of the $21^{\text {st }}$ Century / Ed. by L. Grinin, T. Devezas, and A. Korotayev, pp. 176-187. Volgograd: Uchitel.

Juglar C. 1862. Des Crises Commerciales et de leur retour périodique en France, en Angleterre et aux États-Unis. Paris: Guillaumin.

Juglar C. 1889. Des Crises Commerciales et de leur retour périodique en France, en Angleterre et aux États-Unis. $2^{\text {nd }}$ ed. Paris: Alcan.

Keynes J. M. 1978 [1936]. The General Theory of Employment, Interest, and Money. London: Macmillan.

Kindleberger C. P. 1973. The World in Depression, 1929-1939. London: Allen Lane and Penguin. 
Kleinknecht A. 1987. Innovation Patterns in Crisis and Prosperity: Schumpeter's Long Cycle Reconsidered. London: Macmillan.

Klinov V. G. 2008. World Economy: Outlook to 2050. Voprosy Ekonomiki 5: 62-79. In Russian (Клинов В. Г. Мировая экономика: прогноз до 2050 г. Bопросы экономики 5: 62-79).

Kondratieff N. D. 1935. The Long Waves in Economic Life. The Review of Economics and Statistics 17(6): 105-115.

Kondratieff N. D. 2002. Big Cycles of Conjuncture and the Theory of Forecasting. Moscow: Economics. In Russian (Кондратьев Н. Д. Большие ицильь конъюнктуры и теория предвидения. М.: Экономика).

Korotayev A. V. 2005. A Compact Macromodel of World System Evolution. Journal of World-Systems Research 11((1): 79-93.

Korotayev A. V. 2006. The World System Urbanization Dynamics: A Quantitative Analysis. History \& Mathematics: Historical Dynamics and Development of Complex Societies / Ed. by P. Turchin, L. Grinin, A. Korotayev, and V. C. de Munck, pp. 4462. Moscow: KomKniga/URSS.

Korotayev A. V. 2007. Compact Mathematical Models of World System Development, and How They can Help us to Clarify our Understanding of Globalization Processes). Globalization as Evolutionary Process: Modeling Global Change / Ed. by G. Modelski, T. Devezas, and W. R. Thompson, pp. 133-160. London: Routledge.

Korotayev A. V., and Grinin L. E. 2012a. Kondratieff (K-) Waves in the World System Perspective. Kondratieff Waves. Dimensions and Prospects at the Dawn of the $21^{\text {st }}$ Century / Ed. by L. Grinin, T. Devezas, and A. Korotayev, pp. 23-64. Volgograd: Uchitel.

Korotayev A. V., and Grinin L. E. 2012b. Kondratieff (K-) Waves in the World System Perspective. Kondratieff Waves: Aspects and Prospects / Ed. by A. A. Akaev, R. S. Greenberg, L. E. Grinin, A. V. Korotayev, and S. Yu. Malkov, pp. 23-64. Volgograd: Uchitel. In Russian (Коротаев А. В., Гринин Л. Е. Кондратьевские волны в мир-системной перспективе. Кондратьевские волны: аспекты и перспективы / Ред. А. А. Акаев, Р. С. Гринберг, Л. Е. Гринин, А. В. Коротаев, С. Ю. Малков, с. 58-109. Волгоград: Учитель).

Korotayev A. V., Khaltourina D. A., Malkov A. S., Bogevolnov Yu. V., Kobzeva S. V., and Zinkina Yu. V. 2010. The Law of History: Mathematical Modeling and Forecasting of World and Regional Development. Moscow: LKI/URSS. In Russian (Коротаев А. В., Халтурина Д. А., Малков А. С., Божевольнов Ю. В., Кобзева С. В., Зинькина Ю. В. Законь истории. Математическое моделирование и прогнозирование мирового и регионального развития. 3-е изд., испр. и доп. М.: ЛКИ/URSS).

Korotayev, Khaltourina, Kobzeva et al. 2011 Коротаев А. В., Халтурина Д. А., Кобзева С. В., Зинькина Ю. В. 2011. Ловушка на выходе из ловушки? О некоторых особенностях политико-демографической динамики модернизирующихся систем. Проекты и риски будущего. Концепщии, модели, инструменты, прогнозы / Ред. А. А. Акаев, А. В. Коротаев, Г. Г. Малинецкий, С. Ю. Малков, c. 45-88. М.: Красанд/URSS. 
Korotayev A. V., Malkov A. S., and Khaltourina D. A. 2006a. Introduction to Social Macrodynamics: Compact Macromodels of the World System Growth. Moscow: KomKniga/URSS.

Korotayev A. V., Malkov A. S., and Khaltourina D. A. 2006b. Introduction to Social Macrodynamics: Secular Cycles and Millennial Trends. Moscow: KomKniga/URSS.

Korotayev A. V., and Tsirel S. V. 2010a. A Spectral Analysis of World GDP Dynamics: Kondratieff Waves, Kuznets Swings, Juglar and Kitchin Cycles in Global Economic Development, and the 2008-2009 Economic Crisis. Structure and Dynamics 4(1): 357. URL: http://www. escholarship.org/uc/item/9jv108xp.

Korotayev A. V., and Tsirel S. V. 2010b. Kondratieff (K-) Waves in the World Economic Dynamics. System Monitoring of Global and Regional Development / Ed. by D. A. Khaltourina, A. V. Korotayev, pp. 189-229. Moscow: LIBROCOM/URSS. In Russian (Коротаев А. В., Цирель С. В. Кондратьевские волны в мировой экономической динамике. Системный мониторинг глобального и регионального развития / Ред. Д. А. Халтурина, А. В. Коротаев, с. 189-229. М.: ЛИБРОКОМ/ URSS).

Korotayev A. V, and Tsirel S. V. 2010c. Kondratieff (K-) Waves in the World System Economic Dynamics. Forecast and Modeling of Crisis and World Dynamics / Ed. by A. A. Akaev, A. V. Korotayev, G. G. Malinetsky, pp. 5-69. Moscow: LKI/ URSS. In Russian (Коротаев А. В., Цирель С. В. Кондратьевские волны в мирсистемной экономической динамике. Прогноз и моделирование кризисов и мировой динамики / Ред. А. А. Акаев, А. В. Коротаев, Г. Г. Малинецкий, с. 569. М.: ЛКИ/URSS).

Korotayev A., Zinkina J., and Bogevolnov J. 2011. Kondratieff Waves in Global Invention Activity (1900-2008). Technological Forecasting \& Social Change 78: 12801284.

Korotayev A., Zinkina J., Bogevolnov J., and Malkov A. 2011. Global Unconditional Convergence among Larger Economies after 1998? Journal of Globalization Studies 2(2): 25-61.

Korotayev A., Zinkina J., Kobzeva S., Bogevolnov J., Khaltourina D., Malkov A., Malkov S. 2011. A Trap at the Escape from the Trap? Demographic-Structural Factors of Political Instability in Modern Africa and West Asia. Cliodynamics: The Journal of Theoretical and Mathematical History 2(2): 276-303.

Kuczynski Th. 1980. Have there been Differences Between the Growth Rates in Different Periods of the Development of the Capitalist World Economy Since 1850? An Application of Cluster Analysis in Time Series Analysis. Historical Social Research / Ed. by J. M. Clubb, and E. K. Scheuch, pp. 300-316. Stuttgart: Klett-Cotta.

Kuryaev A. V. (Ed.) 2005. Economic Cycle: Analysis of Austrian School. Chelyabinsk: Socium. In Russian (Куряев А. В. (ред.) Экономический изил: анализ австрийской школь. Челябинск: Социум).

Kuznets S. 1958. Long Swings in the Growth of Population and in Related Economic Variables. Proceeding of the American Philosophical Society 102(1): 25-52. 
Kuznets S. S. 1966. Modern Economic Growth. Rate, Structure and Spread. New Haven, CT: Yale University Press.

Kwasnicki W. 2008. Kitchin, Juglar and Kuznetz Business Cycles Revisited. Wroclaw: Institute of Economic Sciences.

Lan V. I. 1976. USA: From World War I to World War II. Moscow: Nauka. In Russian (Лан В. И. США: от Первой мировой до Второй мировой войны. М.: Наука).

Lazurenko S. 1992. The Problems of Long-Term Fluctuations of Economic Dynamics. Voprosy Ekonomiki 10: 69-75. In Russian (Лазуренко С. Проблемы долговременных колебаний экономической динамики. Вопросы экономики 10: 69-75).

Lescure J. 1907. Des Crises Générales et Périodiques de Surproduction. Paris: L. Larose et Forcel.

Lescure J. 1908. General and Periodical Industrial Crises. Saint-Petersburg: Social Benefit. In Russian (Лескюр Ж. Общие и периодические промыщленные кризисы. СПб.: Общественная польза).

LLSDC. n. d. Sessions of Congress, 1st - 110th Congresses, 1789-2007. URL: http:// www.1lsdc.org/assets/sourcebook/sess-congress.pdf.

Maddison A. 2010. World Population, GDP and Per Capita GDP, A.D. 1-2008. URL: www.ggdc.net/maddison.

Maevsky V. I. 1992. About the Nature of Long Waves. Voprosy Ekonomiki 10: 58-62. In Russian (Маевский В. И. О характере длинных волн. Вопросы экономики 10: 58-62).

Mandel E. 1975. Late Capitalism. London: New Left Books.

Mandel E. 1980. Long Waves of Capitalist Development. Cambridge: Cambridge University Press.

Mankiw N. G. 2008. Principles of Economics. $5^{\text {th }}$ ed. Mason, OH: South-Western.

Mankiw N. G. 1994. Macroeconomics. Moscow: MSU. In Russian (Мэнкью Н. Г. Макроэкономика. М.: МГУ).

Marx K. 1960 [1867]. Capital. Vol. 1. Collected Papers. $2^{\text {nd }}$ Ed. / Ed. by K. Marx, F. Engels. Vol. 23. Moscow: Politizdat. In Russian (Маркс К. Капитал. Т. 1. Сочинения. Изд. 2-е / К. Маркс, Ф. Энгельс, т. 23. М.: Политиздат).

Marx K. 1961. Capital. Vol. 2 [1893], Vol. 3 [1894]. Collected Papers. $2^{\text {nd }}$ ed. / Ed. by K. Marx, F. Engels, Vols. 24-25. Moscow: Politizdat. In Russian (Маркс К. Капитал. Т. 2 [1893], Т. 3 [1894]. Сочинения. Изд. 2-е / Ред. К. Маркс, Ф. Энгельс, т. $24-25$. М.: Политиздат).

Mendelson L. A. 1959-1964. Theory and History of Economic Crises and Cycles. Vols. 1-3. Moscow: Social-Economic Literature Publishing. In Russian (Мендельсон Л. А. Теория и история экономических кризисов и циклов. Т. 1-3. М.: Издательство социально-экономической литературы).

Menshikov S. M., and Klimenko L. A. 1989. Long Waves in Economy. When a Society Renews its Skin. Moscow: Mezhdunarodnye otnoshenya. In Russian (Меньшиков С. М., Клименко Л. А. Длинные волны в экономике. Когда общество меняет кожу. М.: Международные отношения). 
Mills J. 1868. On Credit Cycles and the Origin of Commercial Panics. Transactions of the Manchester Statistical Society 1867-1868: 5-40.

Minsky H. P. 1983. The Financial Instability Hypothesis: An Interpretation of Keynes and an Alternative to 'Standard' Theory. John Maynard Keynes. Critical Assessments / Ed. by J. C. Wood, pp. 282-292. London: Business \& Economics.

Minsky H. P. 1985. The Financial Instability Hypothesis: A Restatement. PostKeynesian Economic Theory: A Challenge to Neo-Classical Economics / Ed. by P. Arestis, and T. Skouras, pp. 24-55. Brighton: M. E. Sharpe.

Minsky H. P. 1986. Stabilizing an Unstable Economy. New Haven, CT: Yale University Press.

Minsky H. P. 2005. Induced Investment and Business Cycles. Cheltenham, UK Northampton, MA: Edward Elgar.

Mises L. von. 1981 [1912]. The Theory of Money and Credit. Indianapolis, IN: Liberty Fund.

Mises L. von. 2005. Man's Activity: Treatise on Economic Theory. Chelyabinsk: Socium. In Russian (Мизес Л. фон. Человеческая деятельность: трактат по экономической теории. Челябинск: Социум).

Mitchell W. C. 1913. Business Cycles. Berkeley, CA: University of California Press.

Mitchell W. C. 1927. Business Cycles: The Problem and its Setting. New York: NBER.

Mitchell W. C. 1930. Economic Cycles. Problem and Its Statement. Moscow: Gosizdat. In Russian (Митчелл У. Экономические цикльы. Проблема и ее постановка. М.: Госиздат).

Modelski G. 1987. Long Cycles in World Politics. Seattle: University of Washington Press.

Modelski G. 2006. Global Political Evolution, Long Cycles, and K-Waves. Kondratieff Waves, Warfare, and World Security / Ed. by T. C. Devezas, pp. 293-302. Amsterdam: IOS Press.

Modelski G. 2008a. Globalization as Evolutionary Process. Globalization as Evolutionary Process / Ed. by G. Modelski, W. R. Thompson, and T. Devezas, pp. 11-29. New York: Routledge.

Modelski G. 2008b. Innovation and Evolution in the World Economy. Human Ecology Economics / Ed. by R. E. Allen, pp. 21-45. New York: Routledge.

Modelski G. 2012. Kondratieff (K-) Waves in the Modern World System. Kondratieff Waves. Dimensions and Prospects at the Dawn of the $21^{\text {st }}$ Century / Ed. by L. Grinin, T. Devezas, and A. Korotayev, pp. 65-76. Volgograd: Uchitel.

Modelski G., and Thompson W. 1992. K-Waves, development of World Economy and International Polititics. Voprosy Ekonomiki 10: 49-57. In Russian (Модельски Дж., Томпсон У. Волны Кондратьева, развитие мировой экономики и международная политика. Вопросы экономики 10: 49-57).

Modelski G., and Thompson W. R. 1996. Leading Sectors and World Powers: The Co-evolution of Global Economics and Politics. Columbia, SC: University of South Carolina Press. 
Modelski G., Thompson W. R., and Devezas T. (Eds.) 2008. Globalization as Evolutionary Process: Modeling Global Change. New York: Routledge.

Morgan M. S. 1991. The History of Econometric Ideas. Cambridge: Cambridge University Press.

Mougy R.1992. Development of the Process of Long-Wave Fluctuations. Voprosy Ekonomiki 10: 76-78. In Russian (Моуги Р. Развитие процесса длинноволновых колебаний. Вопросы экономики 10: 76-78).

Pantin V. I. 1996. Cycles and Rhythms of History. Ryazan: Araks. In Russian (Пантин В. И. Циклы и ритмы истории. Рязань: Аракс).

Pantin V. I., and Lapkin V. V. 2006. Philosophy of Historical Forecasting: Rhythms of History and Prospects of World Development in the First Half of the 21st Century. Dubna: Feniks+. In Russian (Пантин В. И., Лапкин В. В. Философия исторического прогнозирования: ритмы истории и перспективы мирового развития 6 первой половине XXI века. Дубна: Феникс+).

Perez C. 2002. Technological Revolutions and Financial Capital: The Dynamics of Bubbles and Golden Ages. Cheltenham: Elgar.

Perez C. 2010. Technological Revolutions and Techno-Economic Paradigms. Cambridge Journal of Economics 34(1): 185-202.

Perez C. 2011a. The Advance of Technology and Major Bubble Collapses. On Capitalism: Perspectives from the Engelsberg Seminar 2010 / Ed. by A. Linklater, pp. 103114. Stockholm: Ax: son Foundation.

Perez C. 2011b. Technological Revolutions and Financial Capital. Dynamics of Bubbles and Periods of Prosperity. Moscow: Delo. In Russian (Перес К. Технологические револючии и финансовый капитал. Динамика пузырей и периодов процвета-ния. М.: Дело).

Perez C. 2012. Technological Revolutions and the Role of Government in Unleashing Golden Ages. Kondratieff Waves. Dimensions and Prospects at the Dawn of the $21^{s t}$ Century / Ed. by L. Grinin, T. Devezas, and A. Korotayev, pp. 211-218. Volgograd: Uchitel.

Pigou A. C. 1929. Industrial Fluctuations. $2^{\text {nd }}$ ed. London: Macmillan.

Poletaev A. V., and Savelieva I. M. 1993. The Cycles of Kondratieff and Development of Capitalism (the experience of interdisciplinary research). Moscow: Nauka. In Russian (Полетаев А. В., Савельева И. М. Цикль Кондратьева и развитие капитализма [опыт междисииплинарного исследования]. М.: Наука).

Rasler K. A., and Thompson W. R. 1994. The Great Powers and Global Struggle, 1490-1990. Lexington, KY: University Press of Kentucky.

Rennstich J. K. 2002. The New Economy, the Leadership Long Cycle and the Nineteenth K-Wave. Review of International Political Economy 9(1): 150-182.

Rothbard M. N. 1969. Economic Depressions: Causes and Cures. Lansing, MI: Constitutional Alliance of Lansing.

Rumyantseva S. Yu. 2003. Long Waves in Economy: Multifactor Analysis. SaintPetersburg: SPU. In Russian (Румянцева С. Ю. Длинные волны в экономике: многофакторный анализ. СПб.: Изд-во СПУ). 
Sacks J. L., and Larren F. B. 1996. Macroeconomics. Global Approach. Moscow: Business. In Russian (Сакс Дж. Л., Ларрен Ф. Б. Макроэкономика. Глобальный подход. М.: Дело).

Samuelson P. A. 1994. Economics. 2 Vols. Moscow: Algon. In Russian (Самуэльсон П. Э. Экономика: в 2 т. М.: Алгон).

Samuelson P. A., and Nordhaus W. D. 2005. Economics. $18^{\text {th }}$ ed. New York: McGraw-Hill.

Samuelson P. A., and Nordhaus W. D. 2009a. Macroeconomics. $18^{\text {th }}$ ed. Moscow: Williams. In Russian (Самуэльсон П. Э., Нордхаус В. Д. Макроэкономика. Изд. 18-е. М.: Вильямс).

Samuelson P. A., and Nordhaus W. D. 2009b. Macroeconomics. $19^{\text {th }}$ ed. New York: McGraw-Hill.

Schäfer U. 2009. Der Crash des Kapitalismus. Frankfurt: Campus Verlag.

Schumpeter J. A. 1939. Business Cycles. New York: McGraw-Hill.

Schumpeter J. A. 1949 [1911]. The Theory of Economic Development: An Inquiry into Profits, Capital, Credit, Interest and the Business Cycle. Cambridge, MA: Harvard University Press.

Schumpeter J. A. 1954. History of Economic Analysis. London: George Allen \& Unwin.

Schumpeter J. A. 1982. Theory of Economic Development. Moscow: Progress. In Russian (Шумпетер Й. Теория экономического развития. М.: Прогресс).

Shostak F. 2002. Where We are, Where We are Headed. Paper presented at the 'Boom, Bust, and Future' Seminar at Ludwig von Mises Institute (Auburn, AL, January 1819).

Skousen M. 1993. Who Predicted the 1929 Crash? The Meaning of Ludwig von Mises / Ed. by J. M. Herbener, pp. 247-283. Norwell, MA: Kluwer Academic Publishers.

Smith A. 1935. Research on Nature and Reasons of Peoples' Wealth. Vol. 2. MoscowLeningrad. In Russian (Смит А. Исследование о природе и причинах богатства народов. Т. 2. М. - Л.)

Sornette D. 2003. Why Stock Markets Crash. Critical Events in Complex Financial Systems. Princeton, NJ: Princeton University Press.

Suetin A. 2009. About the Reasons of Modern Financial Crisis. Voprosy Ekonomiki 1: 40-51. In Russian (Суэтин А. О причинах современного финансового кризиса. Вопросы экономики 1: 40-51).

Ternyik S. I. 2012. K-Periodicity, Space-Time Structures and World Economics. Kondratieff Waves. Dimensions and Prospects at the Dawn of the $21^{\text {st }}$ Century / Ed. by L. Grinin, T. Devezas, and A. Korotayev, pp. 77-84. Volgograd: Uchitel.

Thompson W. R. 1990. Long Waves, Technological Innovation, and Relative Decline. International Organization 44(2): 201-233.

Thompson W. R. 2000. The Emergence of a Global Political Economy. London: Routledge. 
Thompson W. R. 2012. Energy, K-Waves, Lead Economies, and Their Interpretation/Implications. Kondratieff Waves. Dimensions and Prospects at the Dawn of the $21^{\text {st }}$ Century / Ed. by L. Grinin, T. Devezas, and A. Korotayev, pp. 188-210. Volgograd: Uchitel.

Trakhtenberg I. A. 1963 [1939]. Monetary Crises (1821-1938). Moscow: AN SSSR Publishing. In Russian (Трахтенберг И. А. Денежные кризисы (1821-1938). М.: Изд-во АН СССР).

Tugan-Baranovsky M. I. 1894. Industrial Crises in Modern England, Their Reasons and Nearest Influences on Public Life. Saint-Petersburg: Printing-House of I. N. Skorokhodov. In Russian (Туган-Барановский М. Промышиленные кризисы 8 современной Англии, их причины и ближайшие влияния на народную жизнь. СПб.: Типография И. Н. Скороходова).

Tugan-Baranovsky M. I. 1954. Periodic Industrial Crises. Annals of the Ukrainian Academy of Arts and Sciences in the United States 3(3): 745-802.

Tugan-Baranovsky M. I. 2008 [1913]. Periodic Industrial Crises. Moscow: Directmedia Publishing. In Russian (Туган-Барановский М. И. Периодические промышленные кризисы. М.: Директмедиа Паблишинг).

Varga E. S. 1937. World Economic Crises 1848-1935. Vol. 1. Moscow: OGIZ. In Russian (Варга Е. С. Мировые экономические кризисы 1848-1935 г2. Т. 1. М.: ОГИЗ).

Varga E. S. 1974. Capitalism after World War II. Moscow: Nauka. In Russian (Варга Е. С. Капитализм после Второй мировой войны. М.: Наука).

World Bank. 2014. World Development Indicators Online. Washington, DC: World Bank. URL: http://data.worldbank.org/indicator

Zarnowitz V. 1985. Recent Work on Business Cycles in Historical Perspective: Review of Theories and Evidence. Journal of Economic Literature 23(2): 523-580.

Zwan A. van der. 1980. On the Assessment of the Kondratieff Cycle and Related Issues. Prospects of Economic Growth / Ed. by S. K. Kuipers, and G. J. Lanjouw, pp. 183-222. Amsterdam: North-Holland. 